\title{
DEMOCRACIA EM CIDADES MULTICULTURAIS. RE-SIGNIFICANDO OS SISTEMAS DE TOMADAS DE DECISÃO PÚBLICAS À LUZ DOS DIREITOS HUMANOS DAS MINORIAS
}

\section{DEMOCRACY IN MULTICULTURAL CITIES. RE-MEANING THE PUBLIC DECISION SYSTEMS IN THE LIGHT OF HUMAN RIGHTS OF MINORITIES}

\author{
André Leonardo Copetti Santos ${ }^{1}$ \\ Evelyne Freistedt Copetti Santos ${ }^{2}$ \\ Gabriel Otacílio Bohn Edler ${ }^{3}$
}

\section{RESUMO}

O presente artigo tem como escopo principal analisar algumas possibilidades de re-significação da democracia nos espaços geopolíticos de cidades multiculturais, em função da crise de representatividade que incessantemente vêm sofrendo os sistemas democráticos representativos praticados no âmbito nacional, especialmente pela impossibilidade de efetivação dos direitos humanos ligados à diversidade étnica, cultural e comportamental. A perspectiva metódica adotada é a compreensiva.

PALAVRAS-CHAVE: Democracia; Direitos Humanos; Cidade; Multiculturalismo; Interculturalidade.

\section{ABSTRACT}

This article has as main scope to analyze some possibilities of redefining democracy in geopolitical spaces of multicultural cities, due to the crisis of representation that constantly have suffered representative democratic systems practiced at the national level, especially because the impossibility of realization of human rights linked to ethnic, cultural and behavioral diversity. The methodical approach adopted is comprehensive.

KEY WORDS: Democracy; Human Rights; City; Multiculturalism; Interculturality.

\footnotetext{
1 Pós-Doutorando pela Universidade do Vale do Rio dos Sinos (UNISINOS) e pela Universidade de Santiago do Chile (USACH). Professor permanente do Programa de Pós-Graduação em Direito da UNIJUÍ, IJUÍ, RS e do Programa de Pós-Graduação em Direito da URI, Santo Ângelo, RS. Coordenador Executivo do PPGD/URISAN. Editor da Revista Científica Direitos Culturais. E-mail: andre.leonardo@unijui.edu.br

2 Mestre em Direitos Especiais pelo Programa de Pós-graduação Stricto Sensu - Mestrado em Direito da Universidade Regional Integrada do Alto Uruguai e das Missões, Campus Santo Ângelo/RS (2015). Membro do Grupo de Pesquisa intitulado \&quot; Novos Direitos na Sociedade Globalizada\&quot; , registrado no CNPQ e dos Projetos de Pesquisa Direitos Humanos, Cidadania e Consolidação dos Direitos Sociais: estudos sob a ótica do constitucionalismo contemporâneo e da teoria da complexidade de Edgar Morin. E-mail: evecopetti@hotmail.com

${ }^{3}$ Mestre em Direito pela Universidade Regional Integrada do Alto Uruguai e das Missões - URISAN, Campus Santo Ângelo/RS. Pesquisador do grupo de pesquisa Cidadania e Direitos Culturais: a proteção dos direitos de minorias nos tribunais brasileiros - URI e UNISINOS. E-mail: ge.advocacia@yahoo.com.br
} 


\section{INTRODUÇÃO}

Se a grande meta política dos primórdios da modernidade era combinar democracia e igualdade formal, e o grande desiderato de governação do começo do século XX foi aproximar democracia e igualdade material, é possível pôr em pauta que uma das grandes incitações civilizatórias da contemporaneidade seja ajustar metas de democracia, equidade, diversidade e minorias $^{4}$, pois é inegável que uma das principais características que diferencia a

${ }^{4}$ As concepções de maioria e minoria comumente associadas às distintas perspectivas sob as quais é tomada
a ideia de democracia na modernidade, geralmente traduzem um critério quantitativo. Se pensarmos em
democracia representativa, esse viés é ainda mais reforçado. Entretanto, cremos que qualquer tentativa de
re-significação dos processos democráticos de tomada de decisão pública passe, antes de mais nada, por
uma re-simbolização das concepções de maioria e minoria, de modo a distanciá-las de fundamentos
quantitativos. Pensar processos democráticos inclusivos de minorias necessariamente importa em superar
bases quantitativas. Em perspectivas não quantitativas, podemos pensar maioria e minoria, respectivamente,
como constância/inconstância ou devir; como estado de poder e dominação/estado de falta de poder ou
submissão; como abstração ou concretude; como invisibilidade/visibilidade; como homogeneidade/heterogeneidade ou diversidade; como estabilização/movimento; como territorialização pela média/desterritorialização da média; como heteronomia/autonomia. Uma boa pista teórica para uma compreensão não quantitativa da dicotomia maioria/minoria nos é dada por Deleuze e Guattari (1995). Para esses autores, a noção de minoria, com suas remissões musicais, literárias, linguísticas, mas também jurídicas, políticas, é bastante complexa. Minoria e maioria não se opõem apenas de uma maneira quantitativa. Maioria, para eles, implica uma constante, de expressão ou de conteúdo, como um metro padrão em relação ao qual ela é avaliada. Suponhamos que a constante ou metro seja homem-brancomasculino-adulto-habitante das cidades-falante de uma língua padrão-europeu-heterossexual qualquer (o Ulisses de Joyce ou de Ezra Pound). É evidente que "o homem" tem a maioria, mesmo se é menos numeroso que os mosquitos, as crianças, as mulheres, os negros, os camponeses, os homossexuais... etc. É porque ele aparece duas vezes, uma vez na constante, uma vez na variável de onde se extrai a constante. A maioria, segundo eles, supõe um estado de poder e de dominação, e não o contrário. Supõe o metro padrão e não o contrário. Uma outra determinação diferente da constante seria então considerada como minoritária, por natureza e qualquer que seja o seu número, isto é, como um subsistema ou como fora do sistema. Isto pode ser visto em todas operações, eleitorais ou não, onde se dá o poder de escolha, com a condição que a escolha permaneça conforme aos limites da constante ("vocês não têm que escolher uma mudança de sociedade...). Mas, nesse ponto, tudo se inverte. Pois a maioria, de acordo com os pensadores franceses, na medida em que é analiticamente compreendida no padrão abstrato, não é nunca alguém, é sempre Ninguém - Ulisses - ao passo que a minoria é o devir de todo o mundo, seu devir potencial por desviar do modelo. Há, assim, um "fato" majoritário, mas é o fato analítico de Ninguém que se opõe ao devir-minoritário de todo o mundo. É por isso que propõem Deleuze e Guattari, devemos distinguir: o majoritário como sistema homogêneo e constante, as minorias como subsistemas, e o minoritário como devir potencial e criado, criativo. O problema não é nunca o de obter a maioria, mesmo instaurando uma nova constante. Não existe devir majoritário, maioria não é nunca um devir. Só existe devir minoritário. Certamente as minorias são estados que podem ser definidos objetivamente, estados de língua, de etnia, de sexo, com suas territorialidades de gueto; mas devem ser consideradas também como germes, cristais de devir, que só valem enquanto detonadores de movimentos incontroláveis e de desterritorializações da média ou da maioria. Há uma figura universal da constância minoritária, como devir de todo o mundo, e é esse devir que é criação. Não é adquirindo a maioria que se o alcança. Essa figura é precisamente variação contínua, como uma amplitude que não cessa de transpor, por excesso e por falta, o limiar representativo do padrão majoritário. Ver a respeito DELEUZE, GUATTARI (1995, p. 55-57). 
contemporaneidade globalizada de outros períodos é a marcante presença de variedade e dessemelhança em espaços antes homogêneos, em função da intensificação exponencial dos fluxos, especialmente de pessoas e informações culturais.

O Estado nacional foi o espaço geopolítico histórico onde se desenvolveram os dois primeiros movimentos de combinação governativa entre democracia e igualdade formal e substancial, respectivamente. Entretanto, para o desafio contemporâneo - arranjar democracia, equidade, diversidade e minorias -, os Estados, que ainda guardam em relação às suas principais características uma configuração moderna, parecem dar sinais iniciais de debilidade institucional para o cumprimento de tal tarefa.

Uma das principais causas que pode ser apontada como geradora dessa fragilidade estatal é o significativo aumento da complexidade social, que, por consequência, tem gerado uma ampliação da complexidade estatal e uma quase que inevitável debilitação paulatina de suas funções, para a consecução de seus objetivos e fins.

As diversidades étnico-cultural, comportamental e de suficiências sociais já eram realidades existentes nos Estados-nação nos primeiros momentos da modernidade, mas, hoje, em função da intensificação dos fluxos de pessoas, mercadorias e informações, elas são palpáveis materialmente não somente no macro espaço estatal, mas mais concretamente no âmbito das cidades. A ocorrência de uma aceleração dos processos de diversificação nas cidades, notadamente nas grandes metrópoles, como resultado de uma convergência de múltiplos fluxos de mobilidade humana, determinados por uma variedade de causas, especialmente políticas e econômicas, é um fator de alta impactação não só na ampliação da complexidade social e estatal, mas também no equilíbrio dos sistemas democráticos e na sua capacidade de ordenação das relações sociais.

Em ambientes caracterizados por altos índices de diversidade, cada vez mais surgem situações que têm gerado condições favoráveis para crises permanentes dos sistemas democráticos de tomada de decisão pública, uma vez que ao serem quase que totalmente estatalizados e centralizados nos papéis dos representantes eleitos, não permitem uma participação efetiva de boa parte dos grupos que compõem espectros populacionais caleidoscópicos minoritários. Isto tem resultado, quase que invariavelmente, numa seletividade excludente nos processos decisórios públicos, cuja principal consequência é o não atendimento das 
demandas e necessidades, ou direitos humanos ${ }^{5}$, desses grupos, especialmente em espaços comunitários muito densificados populacionalmente. Há, na verdade, um círculo vicioso formado

${ }^{5}$ Ainda que ambos os termos sejam utilizados como sinônimos, a dogmática jurídica constitucional elaborou,
com um considerável grau de sofisticação teórica, alguns critérios diferenciadores entre as expressões
direitos humanos e direitos fundamentais, podendo aí ser incluída, também, para fins de distinção, a expressão "direitos do homem". Poderíamos, sinteticamente, resumir esses critérios como: espacial de positividade e de efetividade. Ingo Wolfgang Sarlet aponta a vinculação da norma ao direito positivo como primeiro fator preponderante de distinção, e neste aspecto o termo 'direitos fundamentais' se aplica para aqueles direitos do ser humano reconhecidos e positivados na esfera do direito constitucional positivo de determinado Estado, ao passo que a expressão "direitos humanos" guardaria relação com os documentos de direito internacional, por referir-se àquelas posições jurídicas que se reconhecem ao ser humano como tal, independentemente de sua vinculação com determinada ordem constitucional, e que, portanto, aspiram à validade universal, para todos os povos e tempos, de tal sorte que revelam um inequívoco caráter supranacional (internacional) (2006, p. 35 e 36). A expressão "direitos do homem" guarda, neste aspecto, uma relação com a ideia de direitos naturais não, ou ainda não positivados, ou seja, está relacionada com um momento pré-legislativo, ou integra uma espécie de moral jurídica pré-estatal. Esse é o principal critério distintivo no entendimento de Perez Luño que considera que o critério da concreção positiva é o mais adequado para determinar a diferença entre ambas as categorias (1995, p. 46-47). Para os fins do presente trabalho, ficaremos apenas com a diferenciação entre direitos humanos e direitos fundamentais, e neste critério da positividade, nos agregamos a posição de Höffe para quem os direitos humanos ao passarem a formar parte da Constituição, estes, que antes eram somente parte integrante da moral jurídica universalista, convertem-se agora em elementos do direito positivo, em direitos fundamentais de uma comunidade jurídica particular (2000, p. 167-168). Ainda este autor chama a atenção de que esta diferenciação não só se opõe às meras declarações, mas também alerta sobre a origem pré-estatal e supraestatal dos direitos fundamentais. Enquanto que os direitos fundamentais positivos são proclamados por um Estado concreto, pelo que correspondem, sobretudo, aos seus habitantes, os direitos humanos formulam a reclamação elementar de corresponder ao ser humano, somente pelo fato de ele ser o que é. Os direitos humanos, assim, para Höffe, estão, portanto, referidos à pessoa simplesmente como pessoa, enquanto os direitos fundamentais concernem à pessoa enquanto membro de um ente público concreto. Não se dintinguem entre si como direito e moral, mas como direito estatal e pré-estatal. Aqui o direito préestatal responde à razão jurídica ou ao direito moral, é dizer, à moral do que que as pessoas devem umas às outras. Os direitos humanos são, portanto, na visão de Höffe, direitos jurídicos e, ao mesmo tempo, suprapositivos, morais $(200$, p.168). Outro critério de distinção importante refere-se à diferença de efetividade. Apesar de existir uma progressiva positivação interna dos direitos humanos, não poderão tais conceitos ser entendidos como sinônimos, pois a efetividade de cada um é diferente. Neste ponto Ingo Wolfgang SARLET é incisivo ao afirmar que "Além disso, importa considerar a relevante distinção quanto ao grau de efetiva aplicação e proteção das normas consagradoras dos direitos fundamentais (direito interno) e dos direitos humanos (direito internacional), sendo desnecessário aprofundar, aqui, a idéia de que os primeiros que - ao menos em regra - atingem (ou, pelo menos, estão em melhores condições para isto) o maior grau de efetivação, particularmente em face da existência de instâncias (especialmente as judiciárias) dotadas do poder de fazer respeitar e realizar estes direitos" (2006, p. 35 e 36). A partir dessa sucinta diferenciação entre direitos humanos e direitos fundamentais, e para os limites do presente trabalho, utilizaremos a ideia de direitos humanos como categoria referencial por três grandes motivos que estão diretamente ligados com o deslocamento teórico que pretendemos neste trabalho, qual seja, pensar, criticamente, limites e possibilidades de desorbitamento da democracia da esfera geopolítica estatal nacional para a esfera estatal-societal da cidade a à luz da efetivação dos direitos humanos das minorias. Em primeiro lugar, damos preferência à expressão direitos humanos pela sua potencialidade crítica em relação às estruturas normativas institucionalizadas constitucionalmente. A adoção da categoria direitos fundamentais implicaria pensar direitos humanos somente enquanto direitos fundamentais escritos, o que de certa forma ignora seu estado jurídico-moral, mas, também, reduz seu vigor crítico. Seguindo a Höffe, neste aspecto, 
pela exclusão de determinados grupos dos espaços decisórios e pelo não atendimento de suas demandas materiais (direitos humanos): se a minoria é excluída dos processos decisórios públicos, não logra satisfação dos direitos essenciais ligados a sua condição humana, e, num processo de retroalimentação, fica fragilizada nos procedimentos eleitorais.

Tendo em conta que é no espaço das cidades onde a diversidade se materializa mais do que em qualquer outro âmbito, pensamos que as dimensões da cidade são as mais adequadas para solução da equação combinatória entre democracia, equidade, diversidade e minorias. A partir disto, a ideia central que se pretende desenvolver neste trabalho é a de que, em face de um incontornável e inevitável movimento de multiplicação da diversidade nas cidades, com sérias repercussões no (des)equilíbrio dos sistemas democráticos centralizados de tomada de decisão pública, o desencadeamento de processos de relegitimação da democracia passa por uma radicalização das suas possibilidades deliberativas nos espaços multifacetados das cidades, de modo a permitir uma efetiva participação de todos os distintos fragmentos populacionais nos processos decisórios, através de arranjos resolutivos dialógicos interculturais que permitam um alto grau de sustentabilidade democrática. Neste sentido, o modelo democrático representativo moderno-liberal apresenta-se como totalmente insuficiente e ineficaz, pois não permite o estabelecimento desse diálogo.

Assim, uma das facetas de uma crise múltipla da democracia contemporânea constitui-se a partir das restrições de participação (seja pela falta de liberdade, seja pela de competitividade ou

somente aquele que proceda separando claramente os direitos humanos dos fundamentais, e referindo-se logo uns aos outros, poderá aportar, por um lado, a possibilidade de seguir desenvolvendo criticamente, em nome dos direitos humanos, aqueles outros fundamentais que se acham realmente em vigência dentro de um ente comum; e, por outro, formular a tarefa de ampliar a proteção dos direitos fundamentais, mais além do ente comum particular, à coexistência de todos os entes comuns, a uma comunidade jurídica internacional, pois os espaços nacionais de proteção têm, não raro, dentro das possibilidades institucionais ditadas pelas moralidade da maioria, não somente não tutelado direitos de minorias, mas até mesmo, agressivamente, os violado, o que afeta fortemente a competitividade democrática de grupos que não adotam as constâncias majoritárias. Por segundo, há uma forte vinculação da definição de direitos fundamentais ao espaço geopolítico nacional e, portanto, ao direito nacional, situação que dá a essa categoria conceitual um potencial de efetividade não só para manter -, mas também para fomentar espaços de exclusão de minorias - por exemplo imigrantes, que tenham dificuldades de inserção formal no sistema político-jurídico nacional, por não gozarem plenamente de direitos de nacionalidade ou cidadania política e, em decorrência disto, com enormes possibilidades de permanecerem excluídos dos espaços decisórios públicos. Por fim, a categoria direitos humanos, ao desbordar da órbita do Estado-nação e, em consequência, do direito nacional, vincula-se, moralmente, a critérios éticos mais amplos, não ficando restrita a positividades estabelecidas em espaços geopolíticos que podem estar mais vulneráveis a consensos conjunturais ou crises democráticas circunstanciais. Com um caráter temporal mais perene, a categoria direitos humanos parece, em nosso entendimento, mais apropriada para exercícios reflexivos para pensar, inclusivamente, ajustes entre minorias, diversidade e democracia. 
isenção) nos processos públicos de tomada de decisão impostas a minorias e diferentes pelos grupos hegemônicos, social, política e economicamente. Essa crise democrática é amplificada pelo caráter homogeneizador do espaço geopolítico nacional, e uma forte alternativa para sua superação é a potencialização dos espaços participativos não centralizados da cidade, de modo a permitir, de forma mais efetiva, a participação competitiva e autônoma de minorias e diferentes, o que possibilitará a concretização de seus direitos humanos ligados a sua condição não majoritária. É preciso formar um círculo de retroalimentação democrática de modo que a efetivação e a competitividade da participação estejam vinculadas à realização dos direitos humanos vinculados ao status minoritário, e, no sentido inverso e complementar, a efetiva participação possibilite, cada vez mais, a realização de direitos humanos não concretizados.

O quadro teórico a ser utilizado na emolduração do presente trabalho busca articular uma concepção de democracia com suas condições sociais e institucionais, mais especificamente a partir de uma aproximação dos processos de tomada de decisão pública com a efetivação de direitos humanos ligados às condições socioexistenciais minoritárias, nos termos da agency proposta por Guillermo O'Donnel, ou do ajustamento entre Estado de Direito e Estado democrático apresentado por Habermas. O ajuste entre democracia e direitos humanos das minorias é cada vez mais relevante na contemporaneidade, por serem esses os âmbitos sociais mais afetados pelas segregações antidemocráticas.

O método de aproximação utilizado para a elaboração deste trabalho é o dialético, uma vez que o desdobramento dos argumentos abaixo dar-se-á por uma constante confrontação entre as racionalidades políticas da cidade e do Estado-nação. Procedimentalmente, a pesquisa percorre o caminho da investigação bibliográfica e documental.

\section{O AUMENTO DA COMPLEXIDADE/DIVERSIDADE NAS CIDADES CONTEMPORÂNEAS E ALGUNS SINTOMAS DE CRISE DA DEMOCRACIA NACIONAL}

Como ponto de partida do desenvolvimento da pesquisa, é importante tomar em conta o fato inquestionável de que, como bem observa Harvey (2012, p. 459), muitos Estados do mundo atual se caracterizam por ter populações multiétnicas, constituídas lenta ou rapidamente. Inobstante as diferenciações que podem ser feitas em relação à variedade quantitativa e qualitativa de fenômenos de mobilidade humana que ocorreram ao longo da história, em razão das distintas variáveis inerentes a cada caso - populações envolvidas, motivações, estratégias, logísticas etc. -, há uma constante histórica que nelas se afirmou como um elemento imanente 
inafastável das composições sociais decorrentes de processos de movimentações de populações ou grupos menores: a mescla, maior ou menor, potencial ou concreta de pessoas, grupos, povos, nações com diversidades étnicas, culturais e comportamentais.

O fato é que o incremento da diversidade na composição étnica e cultural dessas novas populações já é algo característico da Modernidade, mas com uma agudização nos dias atuais, em função da aceleração dos fluxos causados pelo desenvolvimento tecnológico, especialmente se considerarmos as últimas três ou quatro décadas. Essa configuração pluriétnica e pluricultural de muitos países e cidades foi tomada, por exemplo, por Vertovec para introduzir o termo "superdiversity", a fim de destacar as mudanças às quais se assistiu recentemente na Inglaterra, especialmente salientes na cidade de Londres. A noção de superdiversidade emprega-se para sintetizar uma série de traços que afetam o modo de viver das pessoas. Não só o país de origem ou a etnicidade entram aqui em jogo, mas o conceito abrange aspectos como a condição legal diferencial dos imigrantes (e os direitos associados a cada condição), as pautas de assentamento, seu capital humano e o acesso ao emprego, as diferenças linguísticas, religiosas e comportamentais, o transnacionalismo ou, inclusive, a maneira pela qual respondem a esta diversidade as autoridades, os provedores de serviços e os residentes locais. Mais do que centrarse na ideia de diversidade, em alusão estrita à etnicidade e à procedência de um país determinado, destaca esse autor a existência de múltiplos elementos que produzem esta superdiversidade, concomitantemente à interação de muitos destes eixos de diferenciação (VERTOVEC, 2007, p. 1027-1028).

Ainda que os Estados nacionais guardem, nos dias atuais, boa parte de sua importância geopolítica, há, sem dúvida alguma, novos movimentos que denunciam o início de uma nova geografia da centralidade política, tanto para espaços mais amplos, como o transnacional ou o comunitário regional, como para âmbitos espacialmente mais reduzidos e densificados, como o das cidades.

Esse redimensionamento político do espaço da cidade é identificado por Sassen (2007), quando afirma que hoje em dia, no começo de um novo século, a cidade ressurge como espaço estratégico para entender tendências críticas na reconfiguração da ordem social. Tanto a cidade como a região metropolitana constituem lugares estratégicos para a materialização de certas tendências macrossociais importantes e, portanto, podem se constituir em objeto de estudo. Entre as tendências mencionadas encontra-se a globalização, o auge de novas tecnologias informáticas, a intensificação das dinâmicas transnacionais e translocais, e uma maior presença e voz de instâncias 
específicas da diversidade sociocultural. Diante dessas novas realidades é preciso perguntar: estamos no limiar de uma ressignificação política do nosso Lebensraum, do nosso espaço vital? Estamos, em alguma medida, retornando, ou necessitando retornar, a configurações de espaços decisórios que se aproximam do que ocorreu, em termos geopolíticos, na antiguidade, com a Cidade-Estado?

A cidade antiga foi a grande condição de possibilidade contingencial do acontecimento tanto da filosofia como da democracia, pois foi no espaço citadino que ocorreram o que Deleuze (1992) aponta como as condições de fato da filosofia, e que, longe de qualquer dúvida, são também extensíveis como as condições subjacentes da democracia:

1. Uma pura sociabilidade como meio de imanência, "natureza intrínseca da associação", que se opõe à soberania imperial, e que não implica nenhum interesse prévio, já que os interesses rivais, ao contrário, a supõem;

2. Um certo prazer de se associar, que constitui a amizade, mas também de romper a associação, que constitui a rivalidade; e

3. Um gosto pela opinião, inconcebível num império, um gosto pela troca de opiniões, pela conversação ${ }^{6}$.

A essas três condições (uma pura sociabilidade, um certo prazer de se associar e um gosto pela opinião) associemos, corroborativamente, Lefebvre (2001, p. 82) quando diz que "a Razão teve na Cidade seu lugar de nascimento, sua sede, sua casa. Face à ruralidade, à vida camponesa aprisionada pela natureza, à terra sacralizada e cheia de forças obscuras, a urbanidade afirmava-se como razoável".

Na modernidade, entretanto, mais a democracia que a filosofia tem sofrido um certo afastamento do espaço da cidade, sendo avocada pelo Estado em praticamente todas as suas possibilidades e funcionalidades. A democracia liberal estatalizada, sob a forma de um regime de representação, guarda pouco ou quase nada de sua ancestral mais remota. As atuais democracias representativas, ainda com fortes características liberais, e fortemente vinculadas ao âmbito geopolítico dos Estados nacionais, chamadas criticamente por Dahl como "oligarquias" ou "poliarquias", seriam nominadas por um grego antigo de qualquer outra coisa, menos democracia, pois teriam eles imensas dificuldades em entender como chamar democracia a um sistema no qual o maior comprometimento público do cidadão se produz a cada quatro anos, mediante a eleição de um representante que decide, em seu nome, os destinos de sua existência, em uma assembleia

\footnotetext{
${ }^{6}$ Sobre a sociabilidade pura ver SIMMEL (2006) e MENDRAS (1983).
} 
que dista, na maioria das vezes, milhares de quilômetros da maior parte das cidades onde as pessoas vivem. O distanciamento entre população/povo e representantes eleitos, e, concomitantemente, o caráter oligárquico dos sistemas políticos democráticos estruturados sobre uma base de partidos políticos, pode ser percebido no quadro abaixo, onde se considera o total aproximado da população brasileira no ano de 2015 e os diferentes números de representantes com poder decisório nos diferentes âmbitos da Federação. A divisão do número total da população pelos diferentes números de representantes indica um quociente de representação democrática nos três níveis da Federação, os quais, em nenhum caso, chega próximo ao quociente de representação na democracia ateniense antiga, cuja relação era próximo de 20 para 1 (cada participante da Ekklesia representava algo em torno de 20 moradores de Atenas no seu auge como cidade-estado ${ }^{7}$ ).

\begin{tabular}{|c|c|c|c|}
\hline & $\begin{array}{c}\text { TIPO DE } \\
\text { REPRESENTATE }\end{array}$ & $\begin{array}{c}\text { NÚMERO DE } \\
\text { REPRESENTANTES }\end{array}$ & $\begin{array}{c}\text { QUOCIENTE DE REPRESENTAÇÃO } \\
\text { (POPULAÇÃO TOTAL /No DE } \\
\text { REPRESENTANTES }\end{array}$ \\
\hline \multirow{2}{*}{ UNIÃO } & $\begin{array}{c}\text { Presidente da } \\
\text { República }\end{array}$ & 1 & $\begin{array}{c}205.000 .000 / 595= \\
344.537\end{array}$ \\
\cline { 2 - 3 } & Parlamentares & 594 & $205.000 .000 / 1086=$ \\
ESTADOS- & Governadores & 27 & 188.766 \\
\hline MEMBROS E & Parlamentares & 1.059 & $205.000 .000 / 62.373=$ \\
DISTRITO FEDERAL & Prefeitos & 5.563 & 3.608 \\
\hline MUNICÍPIOS & Vereadores & 56.810 & \\
\hline
\end{tabular}

Do quadro acima é possível concluir que no âmbito onde há uma proximidade uma pouco mais estreita entre representantes e representados - a cidade - os temas decididos têm importância bastante reduzida na vida dos cidadãos, especialmente em uma Federação como a brasileira, com uma forte centralização nas atribuições e competências federais e com uma estreita vinculação às ações dos poderes públicos da União dos temas de interesse da cidade.

\footnotetext{
${ }^{7}$ A razão da dissonância entre como vemos e como nos veriam os gregos se deve, sem dúvida, em primeiro lugar, à enorme distância temporal, mas também às características peculiares da democracia ateniense e ao fato de que grande parte dessas características já não são hoje traços distintivos do que hoje entendemos por democracia. Vejamos três exemplos importantes: A) o centro de poder e de decisão do sistema político ateniense era, de fato, a Assembleia (Ekklesia) de todos os cidadãos, que se reuniam ao menos quarenta vezes por ano e deliberavam sobre leis, finanças, impostos, relações exteriores, ordem pública etc.; B) praticamente todos os postos executivo que surgiam desta Assembleia não eram objeto de eleição, mas de sorteio entre os cidadãos, que os exerciam por breves períodos; C) a justiça estava igualmente nas mãos de jurados populares, muito numerosos e extremamente poderosos (ÁGUILA; PEREZ, 1998).
} 
Por outro lado, fica mais uma vez demonstrado que a democracia representativa estatal nacional é um mito em vários aspectos, especialmente em relação à ideia central à democracia representativa moderna de que as pessoas governam ${ }^{8}$. Os números constantes no quadro acima corroboram em boa medida a famosa "Lei Férrea das Oligarquias", elaborada por Robert Michels para justificar a atuação predominante das cúpulas partidárias no domínio dos sistemas políticodemocráticos nacionais (1982).

Na verdade, uma conclusão que pode ser perfeitamente tirada desses números é a de que o controle social dos processos decisórios democráticos, pela população atingida pelas decisões de caráter público decorrentes do processo democrático, é praticamente inexistente, especialmente em sistemas presidencialistas, com possibilidades de sucessivas reeleições para os cargos legislativos.

Sem dúvida alguma, na sociedade moderna, o Estado nacional subordina a si os seus elementos e materiais, entre os quais a cidade e suas instituições. Atualmente, concordando com Lefebvre (2001), a racionalidade - ao que agregaríamos a ideia de racionalidade política democrática - passa (ou parece passar), ou pretende passar, longe da cidade, acima dela, na escala do território nacional ou do continente. A racionalidade política, em relação às mais graves decisões que afetam populações inteiras, recusa a cidade como momento, como elemento, como condição; só a admite como instrumento e dispositivo, na medida em que concentra seus principais focos de importância num sistema mais amplo e mais dissipado: o sistema democrático nacionalizado.

Outro aspecto da crise da democracia está relacionado com a insuficiência dos sistemas democráticos modernos de ordenar as relações sociais equilibradamente pela tutela dos direitos humanos tanto de maiorias quanto de minorias, mas no caso dos últimos a situação é crítica até mesmo na maioria dos países constitucionalizados. Os sistemas políticos e jurídicos modernos, ao negligenciarem, para dizer o mínimo, a tutela dos direitos humanos de minorias, criaram enormes campos de segregação e violência que afetam diretamente seu caráter democrático de Direito.

\footnotetext{
${ }^{8}$ KARSTEN e BECKMAN (2013) apresentam e refutam 13 mitos acerca da democracia. São eles: 1) Todo voto conta; 2) As pessoas governam em uma democracia; 3) A maioria está certa; 4) A democracia é politicamente neutra; 5) A democracia leva à prosperidade; 6) A democracia é necessária para garantir uma distribuição justa de riqueza e ajudar os pobres; 7) A democracia é necessária para vivermos juntos e em harmonia; 8) A democracia é indispensável para um sentimento de comunidade; 9) A democracia é equivalente a liberdade e tolerância; 10) A democracia promove a paz e ajuda a combater a corrupção; 11) Em uma democracia as pessoas conseguem o que querem; 12) Somos todos democratas; 13) Não há melhor alternativa.
} 
Ao violento campo gravitacional - estrutural e funcional - do Estado, que subtrai de forma cada vez mais extorsiva as possibilidades democráticas da cidade, é preciso adicionar o caráter homogeneizador do sistema democrático estatal nacionalizado, inobstante a ampliação incessante da diversidade étnica, cultural, comportamental, sexual da população no espaço da cidade. A formação histórica das democracias exigiu esforços deliberados de construção nacional que incluíram a consolidação e a difusão de uma cultura comum usada nas instituições sociais, o que de certo modo favoreceu, consideravelmente, alguns grupos sociais com uma proximidade histórica do poder mais efetiva. Com isso, a capacidade dos distintos grupos etnoculturais e de vulneráveis sociais de manterem-se como tais e de garantirem não só espaços de inserção social e política, mas também fluxos que Ihes garantam mobilidade social, reduziu-se drasticamente num cenário político com centros de poder nacionalizados. As demandas de grupos altamente distintos nos espaços densificados das cidades têm se tornado homogeneizadas no espaço político nacionalizado. Marcela Rios Tobar ao fazer um exame detido dos objetivos do sistema democrático aponta alguns sintomas para a crise política atual:

la debilidad democrática está intimamente associada a los vacios de representación producidos cuando: las autoridades públicas electas no expresan la diversidad existente en una comunidad; los ciudadanos y ciudadanas no gozam de um derecho efectivo para presentarse y competir para ocupar cargos públicos; y, existe escasa efectividad de los representantes para mediar entre los intereses de sus representados y el sistema político, a fin de traducir dichos intereses en políticas que logren dar respuesta a sus demandas. $(2008$, p. 13$)$.

No Brasil, e em outros países do mundo como, por exemplo, África do Sul, paradoxalmente, apesar de não possuírem uma configuração social homogeneamente nacional, mas, pelo contrário, multifacetada em seus mais variados aspectos, a base democrática é liberal, e, portanto, nacional e homogeneizadora, o que, em boa medida, contraria frontalmente a configuração social caleidoscópica que o mundo da vida apresenta, especialmente nas cidades, lugares por excelência dessa diversidade.

Nesse sentido, a viabilidade do modelo democrático representativo nacional moderno está assentada solidamente sobre ações políticas homogeneizantes, nas quais o "outro", o estranho, o inimigo não têm lugar. Há uma tendência quase que incontornável de olharmos do Estado para diante, ou seja, do Estado para o planeta, do nacional para o global, ficando a cidade, o máximo possível, num campo de sombras.

É preciso considerar que o Estado e a democracia modernos são estruturas "racionais" voltadas à eliminação da ambivalência, que até então tinha sido a marca referencial da 
institucionalidade medieval e absolutista. Diante do "caos" surgem o Estado nacional e a democracia representativa como a melhor ordem possível. Todas as pluralidades/ambivalências locais deveriam ser postas sob a unidade do Estado e da democracia (esta emergente após um período inicial em que predominaram monarquias constitucionais), dentro de um encadeamento inviolável de verdades liberais e iluministas, com fortes remissões a uma ordem racionalista baseada na liberdade individual. Estado e democracia passaram a constituir uma espécie de ordem política racional universal. Assim, no reino político, Estado nacional e democracia representativa foram estratégias de expurgo da ambivalência pela segregação ou deportação dos estranhos, pelo sancionamento de poderes locais e pela colocação fora da lei daqueles não sancionados, com o preenchimento das "brechas da lei".

As ordens "racionais" estatal e democrática, na execução de suas estratégias e ideologias homogeneizadoras de eliminação da ambivalência, criaram enormes campos sociais de segregação. Em todos os países, ocidentais pelos menos, incontestavelmente, fortes tendências se opõem aos segregacionismos. Não se pode afirmar que a segregação dos grupos, das etnias, dos estratos e classes sociais provém de uma estratégia dos poderes constante e uniforme, nem que deve se ver nela a projeção eficaz das instituições, a vontade dos dirigentes. Mais ainda, das vontades, das ações preparadas que tentam combatê-la. E, no entanto, mesmo onde a separação dos grupos sociais não aparece de imediato com uma evidência gritante, surgem, ao simples exame, uma pressão nesse sentido, e indícios de segregação, que se materializam, são mais evidentes, no espaço da cidade. O caso limite é o gueto. Podemos observar que há vários guetos e tipos de gueto: os dos negros, os das diferentes etnias, os dos homossexuais, os dos intelectuais, os dos operários, os das classes mais abastadas que se isolam em guetos de riqueza. O lazer também tem seus guetos. Como diz Lefebvre (2001, p. 98), "lá onde uma ação preparada tentou reunir as camadas sociais e as classes, uma decantação espontânea logo as separou". O que se pode concluir disso é que os desideratos homogeneizadores do Estado e da democracia liberal modernos sucumbiram e continuam a sucumbir diante da diversidade do mundo da vida, da diversidade que se materializa na cidade, e que, paradoxalmente, é encerrada em guetos segregatórios.

Essas segregações que são, majoritariamente, resultado das ações "ordenadoras" homogeneizantes do Estado nacional, devem ser focalizadas, utilizando uma sistematização de Lefebvre, com seus três aspectos: espontâneo (proveniente de rendas e ideologias); voluntário (estabelecendo espaços separados); programado (sob o pretexto de arrumação e de plano). Por outro lado, o fenômeno da segregação, revelador de uma crise substantiva de nossos sistemas 
democráticos, deve ser analisado segundo índices e critérios distintos: ecológicos (favelas, pardieiros, apodrecimento do coração da cidade [cracolândias, por exemplo]); formais (deterioração dos signos e significações da cidade, degradação do "urbano" por deslocação de seus elementos arquitetônicos; sociológicos (níveis e modos de vida, etnias, culturas, subculturas etc.).

As tendências anti-segregacionistas modernas, apegadas ao humanismo liberal e à filosofia da cidade, encerram um paradoxo, pois ao mesmo tempo em que expressam boas intenções e boas vontades, segregam o diversos como consequências de suas razões práticas ordenadoras e homogeneizadoras. Das razões do fracasso temos fortes indícios. No plano teórico, a separação analítica de um todo inseparável que é a cidade, a comunidade; no plano prático, as estratégias de classes e de grupos (conscientes ou inconscientes) visam à segregação. Disso resulta que, apesar de os poderes públicos, em países democráticos, nos tempos atuais, não poderem decretar publicamente a segregação, ao adotarem uma ideologia humanista, homogeneizante e universalista, transitam em uma zona utópica, para não dizer demagógica, deixando que a segregação prevaleça mesmo em setores da vida social nos quais atuam interventivamente os poderes públicos estatais.

O que é preciso destacar é que as segregações afetam a democracia na cidade muito mais do que no Estado, pois a destroem morfologicamente. Precisamos compreender, assim, que o caráter democrático de um regime é discernido, como alerta Lefebvre, em relação à sua atitude para com a cidade, para com as "liberdades" urbanas, para com a realidade urbana, e, por conseguinte, para com a segregação (2001, p. 99).

Assim, Estado nacional e democracia representativa no espaço nacional, distanciados da materialidade do mundo da vida, surgem como duas grandiosas visões de ordem emergentes na modernidade com a finalidade de solucionar problemas através de algo como uma "mão invisível". São arrimos metafísicos para a emergência de uma pretendida totalidade harmoniosa, onde a autonomia das localidades e funções não poderia passar de uma ficção que decretos e estatutos tornaram plausíveis (BAUMAN, 1999, p. 21). Nesse processo histórico é preciso entender que o objetivo político da modernidade era a constituição de uma nova sociedade livre do caos e da fragmentação, que fizeram, na pré-modernidade, da resolução de problemas um trabalho de Sísifo, em função da carência de um princípio ordenador racional.

Guardadas todas as distâncias espaciais e temporais, guardadas todas as distinções tecnológicas, a questão relativa à importância - ou redução da importância - do lugar da cidade se repete na pós-modernidade ou no mundo globalizado. As imagens que dominam o discurso sobre 
a globalização econômica como a hipermobilidade, a capacidade de comunicação global e a neutralização do território e da distância (SASSEN, 2007, p. 125) tendem, mais uma vez, a lançar o espaço da cidade numa zona gris e de importância política reduzida, ao tomar como um fato a existência de um sistema econômico global, considerando-o como uma função do poder das empresas multinacionais e das comunicações globais, e, como resultado disso, colocando a ênfase no poder e nos atributos técnicos da economia global corporativa.

\section{REPENSANDO A DEMOCRACIA COMO SIMBIOSE E RETROALIMENTAÇÃO ENTRE DIREITOS POLÍTICOS E CIVIS}

A democracia liberal, de caráter fortemente procedimental, baseada na estrutura do Estado-nação, a qual poderíamos caracterizar como uma "democracia cordial" na medida em que se consolidou imaginariamente sobre mecanismos dissimuladores das distâncias sociais e pela vigência de mitos integradores, tem sido substituída irrevogavelmente por uma "democracia cada vez mais partida", na qual a segregação, a agregação seletiva e a desagregação da vida política constituem suas principais marcas.

A Constituição de 1988 pode ser considerada não apenas um divisor de águas político e normativo da democracia brasileira, ou da redemocratização do Brasil, mas também o marco institucional fundante de um regime político no qual a população é instada a exercer um protagonismo na gestão pública, especialmente no plano local. Entretanto, o funcionamento histórico da sociedade brasileira coloca permanentes limites para a consolidação dessa nova ordem democrática, em decorrência dos efeitos das grandes distâncias e ausências de mobilidades sociais que separam as classes, os grupos étnicos, culturais e comportamentais, as regiões, as cidades e até mesmo os bairros, em mundos contrastantes em termos de condições e qualidade de vida.

Para re-significarmos os sistemas de tomadas de decisões públicas à luz da necessidade de inclusão das minorias invariavelmente segregadas, tomamos como ponto de partida a concepção da agency de O’Donnell (1999), na qual um regime democrático - ou poliárquico, na acepção de Dahl (1997) - tem duas dimensões fundamentais (O'DONNELL, 1999): primeiro, é um regime representativo de governo, em que o único mecanismo de acesso às principais posições de governo ocorre por meio de eleições competitivas, resultado da aposta institucionalizada, universalista e includente, que faz uma sociedade, implicando na garantia a todos os indivíduos dos direitos de votar e de ser votado. Segundo, é um regime em que o sistema legal garante as liberdades e direitos considerados fundamentais ao exercício da cidadania política. 
Essa definição implica, para os autores que a adotam, que para um regime ser democrático não basta a realização de eleições, elas devem ser regulares, institucionalizadas e competitivas. Ao mesmo tempo, a definição tem o mérito de afirmar a necessidade de um conjunto de liberdades para garantir a realização de eleições livres, competitivas e isentas. A substancialização da competitividade de uma eleição ocorre, assim, para O'Donnell (1999, p. 589), quando as eleições "reúnem as condições de ser livres, isentas, igualitárias, decisivas e includentes".

É claramente visível no pensamento de O’Donnel uma preocupação em estabelecer uma definição que não se restringe ao foco da institucionalização procedimental da democracia, ou seja, ao acatamento das regras democráticas, e que busque superar a dicotomia procedimentosubstância sobre a qual tem se debruçado de forma mais recorrente a literatura política. Em O’Donnell (1999), estão intrinsecamente vinculados e são inseparáveis esses dois aspectos: a institucionalização do regime e as condições de sua efetividade, traduzidas pelas liberdades fundamentais. Forma (procedimentos eleitorais) e conteúdo (liberdades fundamentais) são inseparáveis na perspectiva de O’Donnel. Nesse aspecto, a democracia liberal procedimentalista incorre no erro de tentar separar forma e conteúdo, num exercício de neutralidade impossível, ao permanecer cega para a incondicionalidade dos fins. A tentativa de separação de forma e conteúdo encerra um paradoxo. Ocorrendo essa separação, temos a forma em sua pureza absoluta, mas sem existência. Não é real, não existe. Separando-se do conteúdo a forma se separa do concreto. Não há forma sem conteúdo; não há conteúdo sem forma. Aquilo que se oferece à análise é sempre uma unidade entre a forma e o conteúdo, e a unidade indissolúvel, uma vez rompida pela análise, é dialeticamente conflitante.

Os direitos de votar e de ser votado, expressos em um sistema legal, definem o que O' Donnnell denomina como agency, concebido como a condição da existência do indivíduo "dotado de razão prática, ou seja, que faz uso de sua capacidade cognitiva e motivacional para tomar decisões racionais em termos de sua situação e de seus objetivos, e dos quais, salvo conclusiva em contrário, é considerado o melhor juiz" (1999, p. 603). A constituição da agency também é produto da aposta da sociedade que mencionamos anteriormente, já que implica na institucionalização de "uma visão moral do indivíduo como ser autônomo, racional e responsável" (p. 615), ou seja, que concebe o indivíduo como "um sujeito jurídico dotado de direitos civis subjetivos" (p. 603). Assim, "as regras que estabelecem a cidadania política são parte essencial de um sistema legal cuja premissa é a concepção de agency de um sujeito jurídico" (p. 615), o que importa dizer que a cidadania política faz parte dos direitos civis, que historicamente a antecederam, como pode ser 
confirmado pela análise histórica dos países de democracia originária, expresso na obra de Marshall (1967). O vínculo entre a cidadania civil e a cidadania política também é defendida por Habermas (1997) que argumenta sobre a "dependência mútua entre as liberdades de ação do sujeito de direito privado e a autonomia pública do cidadão" (p. 314), ou em outros termos, "o nexo interno entre 'direitos humanos' e soberania popular" (p. 316), o que nos remete aos graus de articulação entre a esfera dos direitos civis (Estado de Direito) e a esfera dos direitos políticos e dos procedimentos democráticos (Estado Democrático).

A concepção de agency e a constatação do nexo orgânico e histórico entre direitos políticos e civis nos possibilitam estabelecer um vínculo teórico indissociável entre as condições de efetividade da democracia e as desigualdades sociais e segregações existentes em uma dada sociedade. Ou seja, a impossibilidade da existência real de direitos de cidadania sem o acesso e a garantia de direitos essenciais à existência humana, na medida em que põem em risco a própria possibilidade de escolhas racionais fundadas na autonomia e liberdade de ação. O'Donnell (1999) destaca duas ameaças a serem enfrentadas pela teoria democrática: o problema da miséria e o problema do constante temor à violência, porque ambos "impedem a existência ou o exercício de aspectos básicos da agency, inclusive a disponibilidade de opções mínimas compatíveis com ela" (625).

Dessa concepção de democracia de O'Donnel e Habemas, e socorrendo-nos de Queiroz Ribeiro e Santos Júnior (2003), emergem três questões fundamentais para a nossa discussão. Primeiro, é incontornável a consideração de que os direitos civis estão na base da concepção de cidadania, entendido na sua forma contemporânea, enquanto direitos civis, políticos e sociais (Carvalho, 2001). Segundo, a visão moral subjacente à concepção da agency se funda na visão do indivíduo como sujeito dotado de autonomia (capacidade de se reconhecer), de capacidade cognitiva (ser racional nas suas escolhas) e com integridade de existência (segurança física sem nenhuma forma de coerção). Por fim, como o indivíduo não existe isoladamente, mas sua existência está sempre dependendo de vínculos de pertencimento comunitário, podemos dizer que a dimensão moral e a capacidade de discernimento que é intrínseca a esta abordagem são condições fundamentais para a associação cívica e a participação na dinâmica política.

A questão da cidadania nos remete à discussão da efetividade do regime democrático, entendida como "o grau em que esse sistema de fato ordena as relações sociais" (O'DONNELL, 1999, p. 620). É exatamente a discussão sobre a efetividade que pode elucidar algumas das características da fragilidade do Estado brasileiro e de seus sistemas de tomada de decisão pública. 
Em nossa opinião, a análise de Wanderley Guilherme dos Santos (1993) sobre as dificuldades governativas no Brasil pode ser traduzida exatamente na problemática do grau em que o sistema democrático é capaz de ordenar as relações sociais no Brasil, ou seja, no grau da sua efetividade. Para Santos, apesar de a sociedade brasileira cumprir os requisitos básicos de uma ordem democrática - a institucionalização da competição pelo poder e a extensa participação política -, verifica-se uma contradição expressa na existência de um híbrido institucional, "que associa uma morfologia poliárquica, excessivamente legisladora e regulatória, a um hobbesianismo social préparticipatório e estatofóbico" (Santos, 1993, p. 79). Assim, teríamos a existência e o funcionamento de instituições democráticas normais, em convivência com uma cidadania não poliárquica, expressa pela baixa capacidade participativa, pela reduzida taxa de demandas, pelo descrédito na eficácia do Estado e pela existência de uma cultura cívica predatória, situação profundamente agravada em relação às minorias. Nos termos formulados por O’Donnell (1999), a conclusão parece evidente: nosso sistema democrático não seria, portanto, capaz de ordenar as relações sociais, tendo baixa capacidade de efetividade.

Podemos, então, dizer que se:

1. Por um lado, sob o ponto de vista formal/legal, as dimensões de um regime democrático estão ancoradas em um sistema legal, definido pelo Estado Nacional enquanto entidade territorial, que estabelece os limites de quem é portador dos direitos de cidadania e garante a atribuição universalista e includente desses direitos; e

2. Por outro lado, sob o ponto de vista da efetividade, o regime democrático depende das condições de exercício efetivo dos direitos de cidadania, das quais depende a constituição da agency, ou seja, a habilitação dos cidadãos para participar da dinâmica democrática.

Entendemos, desta forma, que a habilitação está relacionada aos atributos da agency como condição fundamental para a efetividade da democracia, e associada não apenas à existência dos direitos formais, mas às possibilidades de inclusão social dos indivíduos no conjunto de laços, valores, normas que expressam a aposta da sociedade na vida democrática.

Enquanto as desigualdades e segregações sociais produzem condições desfavoráveis à participação cívica dos cidadãos, desabilitam e geram assimetrias de poder, a participação sociopolítica produz capital social e habilita os cidadãos na disputa em torno do exercício dos direitos de cidadania, e, portanto, em torno da própria inclusão social.

Os diferentes arranjos institucionais que coordenam e regulam a relação entre governo e sociedade interferem diretamente na tensão entre direitos, constituição de identidades e 
participação cívica. Assim, na visão de Queiroz Ribeiro e Santos Júnior (2003), com a qual nos associamos, a institucionalização de práticas de governança democrática, bem como o sucesso de experiências locais de governo no contexto da produção de políticas públicas responsivas em relação aos seus cidadãos, estão relacionadas à maneira como se organizam esses arranjos (BOSHI, 1999), no sentido de:

1. bloquear ou minimizar as práticas clientelistas vigentes e a captura das esferas públicas por interesses coorporativos e particularistas;

2. gerar práticas e estruturas horizontais, experiências de participação e capital social;

3. empoderar grupos sociais em situação de vulnerabilidade e exclusão de forma a reduzir o impacto das relações assimétricas de poder; e

4. reforçar vínculos associativos dos grupos locais, suas mobilizações e suas organizações representativas, de forma a incentivar e fortalecer as relações de interação entre os diferentes atores com presença na esfera pública.

Dependendo desses fatores, mesmo em contextos sociais semelhantes, os arranjos institucionais construídos podem determinar resultados muito diferentes quanto ao capital social mobilizado e à instituição de práticas democráticas.

\section{A DEMOCRACIA ENTRE A ARTIFICIALIDADE HOMOGENEIZADORA DO ESTADO-NAÇÃO E A "NATURALIDADE" DIVERSIFICADORA DAS CIDADES CONTEMPORÂNEAS. SUBSTANCIALIZANDO O ESTADO DEMOCRÁTICO DE DIREITO COM A CIDADE DEMOCRÁTICA DE DIREITO}

A democracia moderna está associada fortemente à concepção política do Estado-nação e ao modelo jurídico do Estado de Direito. Pelo viés do Estado-nação, o sistema democrático representativo, baseado na vontade da maioria, tende necessariamente à homogeneização e à exclusão do "outro", do "diverso", dos que não estão inseridos na constância do sistema político e de valores compartilhados; já sob a perspectiva do Estado de Direito, o direito à nacionalidade carrega consigo uma propensão de forçar a assimilação a culturas hegemônicas dentro do espaço geopolítico de controle estatal nacional, mediante um sistema de ônus e bônus àquele que o adquire.

Segundo Hobsbawn (2013), o significado primário de "nação", um dos mais frequentemente utilizados na literatura, era político. Esse conceito igualou "o povo" e o Estado à maneira das Revoluções Americana e Francesa, uma equação à qual é familiar em frases tais como 
"o Estado-nação", as Nações Unidas". Diferentemente, foram os discursos políticos no início dos EUA, os quais preferiam falar "do povo", da União", "da Confederação", "da nossa terra comum", "do público", "do bem-estar público", ou "da comunidade", a fim de evitar a centralização e as implicações unitárias do termo "nação" contra os direitos dos Estados Federados. Por isso foi, ou certamente logo se tornou parte do conceito de nação na era das Revoluções, que ela deveria ser, numa frase francesa, "uma e indivisível". A nação assim considerada era o corpo de cidadãos, cuja soberania coletiva constitui o Estado, o qual era sua expressão política. Assim, fosse o que a nação fosse, os elementos da cidadania e da participação ou escolha em massa jamais estiveram ausentes dela.

Já Stuart Mill não definia a nação meramente pela sua posse de sentimento nacional. Ele também acrescentou que os membros de uma nacionalidade "desejam estar sob o mesmo governo, e desejam que eles devam ser governados por si próprios ou por uma porção deles exclusivamente" (2007). O que é preciso observar nesta definição de Mill é a ligação entre o conceito de nação e o de governo representativo ou democracia representativa.

A equação nação $=$ Estado = povo, e especialmente soberania popular, indubitavelmente ligou nação ao território, e desde então a estrutura e a definição de Estado foram essencialmente territoriais. Na verdade, os contornos fáticos do que viria a ser o Estado moderno inicia, no final do século XV, com as concentrações de territórios e funções pelos monarcas que, paulatinamente, tornaram-se absolutos. Um movimento de poder muito mais do que qualquer unidade orgânica sociocultural determinou a configuração da organização política moderna.

Quanto a esse aspecto, precisa é a análise de Hobsbawn, que, de certa forma, corrobora essa artificialidade do Estado na modernidade. Para ele:

In particular there was no logical connection between the body of citizens of a territorial state on one hand, and the identification of a "nation" on ethic, linguistic or other grounds or of other caractheristics which allowed collective recognition of group membership.

Indeed, if the "nation" had anything in common from the popularrevolutionary point of view, it was not, in any fundamental sense, ethnicity, language and the like, though these could be indications of collective belonging also. As Pierre Vilar has pointed out, what characterized the nation-people as seen from below was precisely that it represented the common interest against particular interests, the common good against privilege, as indeed is suggested by the term Americans used before 1800 to indicate nationhood while avoiding the word itsel. Ethnic group differences were from this revolutionary-democratic point of view as secondary as they later seemed to socialists (2013, p. 20). 
Por outro lado, é preciso ressaltar, mais uma vez, nesse processo de construção artificial do Estado moderno, a importante e grave função homogeneizadora desempenhada pela adoção de línguas nacionais. As linguagens oficiais dos tribunais, dos órgãos burocráticos administrativos e dos cartórios forçaram grupos étnicos e linguísticos distintos, que compunham uma mesma população residente em territórios que se encontravam sob uma idêntica autoridade política central, a adotar uma língua nacional, sob pena de verem-se impedidos de realizar qualquer espécie de negócio com os poderes públicos. Essa situação, de maneira muito contundente, exerceu uma fortíssima influência na liquidação de ambiguidades próprias de espaços geopolíticos menores, como as cidades, aldeias ou outros tipos de comunidades.

Nesse sentido, o acontecimento do Estado nação - e os saberes que the são conexos constitui-se numa total antítese não só ao modelo geopolítico medieval, mas também ao da cidade, ou de qualquer modelo geopolítico que se estruture sobre uma base de ambivalências. Sobre isto, seis razões nos parecem importantes e merecem ser destacadas:

1. O modelo estatal nacional significa a superação dos modelos geopolíticos feudal e citadino, especialmente em relação à ampliação das fronteiras, pois no modelo da cidade antiga os muros eram o limite, enquanto no medievo havia, no máximo, uma proteção dos limites da propriedade-território do príncipe;

2. O modelo geopolítico do Estado-nação, sendo o resultado de um processo de aglutinação, de concentração de territórios e de funções, contraria drasticamente os modelos prémodernos, caracteristicamente fragmentados e ambivalentes, porém, paradoxalmente densos em sua aproximação comunitária, o que de certa forma facilitava as decisões comunitárias;

3. O modelo de Estado-nação coloca a demanda, em função da extensão dos territórios adjudicados pelos príncipes, de uma nova forma de governar, não mais familiar, irresponsável, na qual os súditos eram usados fundamentalmente para a principal finalidade do poder político medieval, a proteção do território-propriedade. Num movimento histórico diverso, o Estado-nação coloca a exigência de uma arte da governamentalidade republicana, onde a população passa a ser não mais um instrumento de proteção do território, mas, em sentido totalmente distinto, uma das finalidades centrais dos atos dos governantes e o elemento principal da legitimidade do poder político. Neste sentido, a constituição de imaginários nacionalistas passa a ocupar importantes espaços não só no seio das populações dos Estados nacionais, mas também constitui 
critérios de tomada de decisão para os detentores do poder político, especialmente para o estabelecimento de uma diferenciação dos interesses internos/sedentários do Estado e da sociedade nacionais e dos interesses externos;

4. O movimento do Estado-nação pode ser compreendido como um movimento de homogeneização forçada de populações muitas vezes distintas e, em consequência, relacionadas, obrigatoriamente, ao espaço geopolítico nacional;

5. Sendo o resultado de processos de aglutinação, concentração e homogeneização, o Estado-nação constitui-se numa clara antípoda a tudo o que possa simbolizar a ambivalência das cidades. Essa situação de antítese entre Estado-nação e cidades leva, naturalmente, à constituição do Estado-nação como o lugar empírico e teórico privilegiado de problematização e de elaboração de saberes problematizadores do outro, do externo, do estrangeiro, do migrante, do estranho ao nacional, do diverso à homogeneidade. O que queremos destacar é que o Estado-nação, suas práticas e seus saberes, constituíram um substrato necessário e suficiente para a elaboração de uma problemática sobre o fenômeno das mobilidades e diversidades humanas, justamente por estas contrariarem a lógica e os valores fundamentais do Estado-nação; e

6. Por fim, queremos destacar a crise atual do Estado-nação, tanto em sua perspectiva territorial, quanto em relação aos seus objetivos homogeneizadores, como ponto importante a ser considerado na sua relação com o acontecimento de condições para a construção de saberes problematizadores das mobilidades e diversidades humanas.

Esse processo de homogeneização se completa com as democracias representativas modernas, pelas quais todos os cidadãos, independentemente de suas diferenças, passaram a ter seus destinos, pelo menos em termos públicos, decididos por instituições unificadas e unificadoras da vida nacional. E nesse aspecto, concomitantemente ao acontecimento do Estado-nação, o fenômeno do Estado de Direito é também de fundamental importância para o estabelecimento de um discurso problematizador dos espaços da cidade, na medida em que com ele surge a tecnologia jurídica de proteção dos valores e interesses do Estado nacional.

O modelo do Estado constitucional de Direito, forma de organização político-jurídicoadministrativa característica da modernidade, encontra, nos diferentes estratos dos seus sistemas positivos de direitos fundamentais, a sua forma paroxística de constituição e proteção da cidadania nacional, colocando, via de regra, o espaço da cidade em uma situação de total excepcionalidade. Para isto, houve, e ainda há, a necessidade de construção de um conjunto de saberes voltados à 
segurança do espaço e do cidadão nacional em detrimento dos âmbitos de desenvolvimento da democracia na cidade. O modelo de Estado de Direito, em convergência com o modelo do Estadonação, propiciou a consolidação de uma cultura e de uma tecnologia político-jurídica de proteção do nacional e, ao mesmo tempo, como lado reverso da moeda, de uma cultura e de uma tecnologia de restrições à esfera decisória citadina.

A uma primeira mirada, assim, os modelos de Estado-nação e de Estado de Direito, guardam perspectivas restritivas voltadas a uma consolidação política de nacionalização das ações de condução a partir de um território e de uma autoridade central.

Nesse aspecto é importantíssimo considerar o papel que têm jogado os direitos fundamentais de nacionalidade e políticos. Estas duas espécies de direitos fundamentais são as bases funcionais jurídicas mais fortes da lógica do Estado-nação, pois através delas é que se estrutura a vinculação das pessoas a um território nacional, a uma autoridade central e a um sistema de direitos, cujos processos de decisão e execução estão totalmente distanciados das possibilidades de ações dos poderes públicos municipais.

Esse distanciamento significa, dentre outras coisas, a negação de qualquer traço de identidade entre governantes e governados. A afirmação do princípio da democracia representativa, especialmente no espaço nacional, nega qualquer possibilidade de identidade essencial entre os eleitores e os que, em seu nome, exercem o poder (GUEDES, 2013, p. 673). Ainda que uma pretensão de identidade absoluta entre governantes e governados seja própria de regimes totalitários, e, portanto, indesejável, a versão contrária também o é: a total falta de identidade entre os cidadãos e seus representantes e a quase que inexistência completa de possibilidade de fiscalização das suas ações, causadas em significativa medida pelo afastamento dos principais dirigentes políticos dos espaços vitais das cidades, colocam, pelo menos, a necessidade de repensar a centralidade política nacional, assim como a revalorização do espaço decisório da cidade.

Se o Estado moderno é marcado por essa artificialidade organizacional e institucional, a cidade, em sentido contrário, guarda certa naturalidade dos processos de aglutinação e organização da humanidade. A cidade supera em muito a simples institucionalidade do Estado. Conforme Park:

A cidade é algo mais do que um amontoado de homens individuais e de conveniências sociais, ruas, edifícios, luz elétrica, linhas de bonde, etc.; algo mais também do que uma mera constelação de instituições e dispositivos administrativos - tribunais, hospitais, escolas, polícia e funcionários civis de 
vários tipos. Antes, a cidade é um estado de espírito, um corpo de costumes e tradições e dos sentimentos e atitudes organizados, inerentes a esses costumes e transmitidos por essa tradição. Em outras palavras, a cidade não é meramente um mecanismo físico e uma construção artificial. Está envolvida nos processos vitais das pessoas que a compõem; é um produto da natureza, e particularmente da natureza humana (1979, p. 26).

Como decorrência lógica da ideia de que a cidade é o local dos homens e de suas culturas, a urbe é, por excelência, o local da democracia: nela os processos democráticos, ou sua ausência, se tornam palpáveis, sensíveis, escapando à mera discussão teórico-acadêmica, tornando-se viva. Não se pode mais falar, portanto, sobre cidades, sem se falar sobre democracia e, mais ainda, não se pode mais discutir ou sequer se conceber a ideia de democracia afastada da percepção sobre os aspectos multiculturais da cidade contemporânea.

A questão que se põe é: a multiculturalidade urbana é uma garantia de democracia ou é necessário darmos um passo além e buscarmos um processo de integração entre as culturas componentes do tecido urbano? Seria a interculturalidade o caminho para esta integração?

O que se verifica, de forma clara, é que a tendência à multiculturalidade é histórica, inexorável e cada vez maior, pois este construto que antes se dava pelo fluxo de pessoas trazendo o contato direto com o outro, com o diferente, agora se encontra aumentado e incontrolável, dado que, na atual era da sociedade em rede como bem apresenta Castells (2010), a troca de informações, os contatos com as mais variadas identidades através da mídia, da internet, torna praticamente impossível que um grupo permaneça isolado, intocado por identidades diversas, quanto mais, grupos que se encontram no espaço concreto das cidades.

Com o decorrer dos anos, essa multiplicidade de culturas tornou-se maior, mais sutil, no sentido de que não só mais se verifica uma simples dicotomia ricos/pobres, detentores do capital/proletários, mas sim uma complexidade de identidades individuais e comunitárias, grupos que se reúnem em torno de cultos e características comuns, e que, não raro, entram em conflito com outras comunidades. Nesse sentido, o pensamento pós-estruturalista desafia o liberalismoindividualista, bem como a análise de classe marxista, ao afirmar que a diferenciação social está baseada em múltiplas fundações, incluindo raça, etnicidade, gênero, religião e cultura.

A teoria democrática liberal, ao tratar os indivíduos atomizadamente, ignora o enraizamento das pessoas em classes, gênero, culturas e relações familiares; não está preocupado com o reconhecimento do "outro". Em sentido diverso, Marx, ao insistir na importância das relações de produção mais do que na das relações de distribuição ou reprodução como fonte da exploração e da desigualdade, reduz drasticamente o problema da diversidade ao problema 
econômico, e em decorrência disto restringe quase que totalmente a questão democrática à dicotomia das relações entre capitalistas e proletários.

Assim, é preciso pensar que, longe do simples solipsismo liberal, ou das relações econômicas de classe marxista, a produção de espaços decisórios inclusivos é muito mais complexa. Há, muito além disso, culturas comunitárias com fortes vínculos com a conformação de identidades, gerando o que Castells (2010) chama de "paraísos comunais", ligações identitárias extremamente fortes, mas que, ao mesmo tempo, se permeiam pela multiplicidade de interesses de cada indivíduo que compõe a comunidade, podendo conviver, por exemplo, católicos e evangélicos unidos por um forte senso comunitário quando residentes em um mesmo espaço geográfico, em especial um espaço de exclusão, como as favelas, por exemplo.

Essa percepção da construção do espaço explica muito do aspecto multicultural urbano brasileiro na atualidade: um lócus pluricultural, porém com forte aspecto de guetificação, mantendo as comunidades e grupos culturais diversos em constante estado de tensão, incapazes de interagir com o diferente, demarcando seu território como forma de defesa, tanto no aspecto físico como identitário.

Tem-se, assim, uma multiculturalidade estática, desprovida de diálogo, um mero agrupamento de culturas em um mesmo território político-geográfico, como bem pontua Sennet (2010, p. 368)

Hoje, à medida que a experiência corporal cria guetos individuais, o medo do contato que deu origem ao isolamento dos judeus no Renascimento ganhou força na sociedade moderna, em que indivíduos criam guetos em suas experiências corporais quando confrontados com a diversidade.

Verifica-se uma busca de isolamento do indivíduo e de grupos culturalmente idênticos, em espaços limitados de afastamento do outro, do diverso, do diferente, causando um estranhamento cada vez maior, em especial porque, cada vez mais, há a necessidade de contato com o externo, havendo, portanto uma constante tensão nessa dialética comunidade local/todo global. Conforme Lucas (2013, p. 167/168):

É possível afirmar, portanto, que a sociabilidade contemporânea engendrada pela globalização produz contradições em todas as esferas sociais. Não é somente a economia que apresenta sua face globalizadora. Ocorre, também, uma globalização das 'biografias', uma reinvenção do global e do local que afeta a individualidade de cada um.

Este aspecto do multiculturalismo pode mostrar-se pernicioso, tornando a urbe palco de conflitos perenes e de desconstrução da democracia. Daí a necessidade de um avanço em direção à interculturalidade, à capacidade de composição dos conflitos ou, mesmo, à prevenção de sua 
criação, através do diálogo intercultural, da quebra das barreiras e muros, físicos ou identitários, culturais e ideológicos que separam os habitantes da cidade.

A dificuldade de lidar com essa tensão que modifica a própria identidade individual dos habitantes da cidade, que ao mesmo tempo em que são globais têm forte vínculo com o espaço que ocupam (tanto territorial como social, religioso, ideológico) traz a necessidade de uma revisão dos espaços urbanos e da dialética dos grupos que habitam a cidade. Para Santos:

A cidade não é, como bem aponta Morin, Lévi-Strauss, Pesavento, Flusser e outros tantos, uma simples projeção territorial baseada em relações socioeconômicas. No debate sobre a cidade, o reconhecimento da existência de uma espacialidade anterior à do espaço urbano exige que se leve em conta os mitos fundadores. Certamente, não se trata dos fantasmas do arquiteto ou do investidor, mas de suas ideias, que participam de uma finalidade social ou até mesmo a insuflam. Se a cidade é uma entidade material, um constructo socioeconômico, uma narrativa que permite a articulação entre os dois, refletir sobre a cidade do amanhã resulta de uma providência cultural destinada a encontrar os fundamentos de um laço entre o local e o global, o contexto urbano e o contexto natural, a exigência de mobilidade e a identidade para todos (2013, p. 98).

Tem-se, portanto, uma premência de equilíbrio entre os diversos grupos componentes da urbe que leva ao conceito de sustentabilidade democrática. Temos que pensar que uma sustentabilidade democrática pode se alcançada num espaço que podemos denominar como a Cidade Democrática de Direito, onde a participação das minorias possa ser garantida de uma forma mais efetiva e competitiva, e onde seus direitos humanos ligados às suas condições de diversos ou minoritários possam ser materializados de forma mais concreta e substancial, fora da centralidade dos poderes públicos. É preciso conceber alternativas para que no espaço da cidade a democracia seja exercida de forma distinta à que the corresponde no espaço nacional. O âmbito da cidade é o lugar dos rizomas, dos encurtamentos de distância, que na extensão do Estado tornam-se invisíveis e impalpáveis, situação que dificulta enormemente a participação competitiva no jogo democrático, especialmente para os grupos sociais que não seguem as constâncias da maioria.

Diante de suas crises e da crescente importância que têm assumido as cidades nos mais distintos aspectos da vida nacional, urge pensarmos modulações da ideia germinal de Estado de Direito, mais ligada ao Estado-nação, para uma concepção de Estado de Direito onde as suas dimensões, estruturas e funções, que ora são majoritariamente nacionais, possam ser deslocadas para o espaço geopolítico e jurídico da cidade. A forma política atual da cidade é uma replicação despotencializada da forma centralizada do Estado. É preciso vigorizar a participação e a ação comunitárias como alternativas aos poderes executivos e legislativos municipais. 
Um conceito de Cidade Democrática de Direito deve ser articulado a partir de uma autonomia da cidade dentro do sistema federativo, que ultrapasse os limites do que a Constituição Federal define, em seu artigo 30, como "interesse local". Essa concepção de autonomia recepciona residualmente o que não é de interesse nacional e estadual. Para além disso, é preciso compreender a cidade como o espaço privilegiado, tanto quanto ou até mais que o estadual ou federal, para a concretização dos direitos humanos. Nesse sentido, ao ser a cidade o espaço de materialização da diversidade - étnica, cultural, comportamental - das minorias em um sentido geral -, é nela que devem se constituir os principais espaços públicos de decisão que potencializem a participação dos diferentes grupos comunitários e, consequentemente, a concretização dos interesses que são imanentes à condição da diversidade ou da minoria. É na cidade que deve, em primeiro lugar, concretizar-se a agency nos termos propostos por O'Donnel, ou o ajuste entre Estado democrático e Estado de Direito, conforme apresentado por Habermas.

É importante considerar que o caráter excepcional da diversidade e das minorias no âmbito do Estado é ainda mais excepcional no espaço das cidades. Comumente, a presença do diverso ou do minoritário no cenário decisório público estatal não se reflete com a mesma intensidade no âmbito citadino, e, assim, é preciso garantir a participação do diverso ou do minoritário de forma mais efetiva nos sítios de tomada de decisão da comunidade.

A ideia de uma Cidade Democrática de Direito, onde a agency das minorias seja estabelecida e fortalecida, significa uma substancialização do conceito de Estado Democrático de Direito, pois sendo potencializados os processos de tomada de decisão pública na cidade, também serão revigorados, se vislumbrados desde a perspectiva do Estado Democrático de Direito, os próprios processos do Estado em seus âmbitos políticos microcósmicos.

É preciso superar esse modelo centralizado estatal que se repete na cidade, pois é no espaço mais densificado socialmente da comunidade onde há uma materialização do caráter rizomático e de rede da sociedade. Precisamos institucionalizar de forma mais efetiva processos públicos de tomada de decisão, dentro da extensão da cidade, que traduzam de uma forma mais fiel as proximidades comunitárias que somente existem de forma concreta na cidade. Estado Democrático de Direito e Cidade Democrática de Direito são dois conceitos complementares, e o arranjo dessas suas variáveis é de fundamental importância para uma re-significação dos processos de tomada de decisão pública, que se faz ainda mais urgente em países como sérios déficits de democracia, especialmente para as minorias. 


\section{POSSIBILIDADES DA DEMOCRACIA A PARTIR DE MODELOS TEÓRICO/PRÁTICOS DE INTEGRAÇÃO DE DIREITOS HUMANOS EM AMBIENTES DE ALTA DIVERSIDADE}

Uma questão importante para a concretização da agency ou do ajuste entre Estado democrático e Estado de Direito, numa Cidade Democrática de Direito, de forma que as minorias tenham competitividade democrática, e não apenas participação formal, nos processos públicos de tomada de decisão, cinge-se ao arranjo de efetividade que deve ser estabelecido entre os direitos humanos de maiorias e minorias. Devem os direitos humanos das minorias ser integrados às constantes valorativas majoritárias, devem fundir-se com os da maioria, criando um novo modelo, ou devem ser preservados em sua diferença e multiplicidade de forma a garantir identidades e autonomia? A composição desse arranjo pode ser analisada e projetada a partir de modelos teórico-práticos de integração de direitos humanos em ambientes com alta complexidade em função de sua diversidade.

As democracias representativas nacionais, desde suas primeiras versões oitocentistas, encerram, em termos de ambivalência cultural e comportamental, fortes características assimilatórias, totalmente inadequadas para a consolidação democrática em sociedades com alto grau de diversidade, as quais exigem ações políticas mais efetivas para arranjos entre democracia, diversidade e minorias. Uma abordagem assimilacionista (BARKAN, 1995 e 2006; BRUBAKER, 2001) sustenta-se sobre a ideia central de que os diferentes, os "outros" abandonem seus costumes e práticas originais, adequando seu comportamento de acordo com os valores e normas da maioria. Assim, devem mudar sua língua, vestimentas, estilos de vida e perspectivas culturais como parte da integração à sociedade da maioria. Segundo Harvey, nos Estados Unidos, conhecidos como uma "nação de imigrantes", gerações dos "outros" que vinham de fora foram submetidas a pressões para se "assimilarem" dessa forma, e muitos dos seus filhos se tornaram "americanos" mais ou menos completos como resultado disto. Também de acordo com o mesmo autor, a maioria das políticas oficiais do Reino Unido visa à assimilação de imigrantes à sociedade britânica (2012, p. 460).

Assim, a participação dos diferentes minoritários nos processos públicos de tomada de decisão pode ser competitiva se as diferenças forem assimiladas, se eles forem majoritariamente normalizados. Mas na medida em que são desdiferenciados, os grupos minoritários perdem também o vigor em suas razões públicas para defender espaços para suas diferenças. 
Diferente do assimilacionismo, o modelo do melting $\operatorname{pot}^{9}$ propõe que em vez das tradições dos diferentes e minoritários se dissolverem em favor da dos dominantes entre a população preexistente, elas devem ser mescladas e formar padrões culturais novos e evoluídos. Com suas atrações para uma variedade diversa de grupos étnicos, diz-se que os Estados Unidos são a melhor demonstração do padrão associado à ideia do melting pot. À medida que os grupos minoritários se adaptam aos ambientes sociais mais amplos em que se encontram, não apenas são "trazidos" valores e normas culturais diferentes de fora da sociedade, como também se cria mais diversidade (BUREAU OF CENSUS [U.S. DEPARTMENT OF COMMERCE, s.d.]; JACOBY, 2004; GANS, 2004).

Muitos acreditam que o modelo do melting pot é o resultado mais desejável de integração em sociedades com alta diversidade, especialmente étnica. As tradições e os costumes das populações imigrantes, por exemplo, não são abandonadas, mas contribuem e definem um meio social em constante transformação. Formas híbridas de culinária, moda, música e arquitetura são manifestações da abordagem melting pot. Até certo grau, segundo Harvey, esse modelo é a expressão exata de certos aspectos do desenvolvimento cultural norte-americano. Embora a cultura "anglo" tenha permanecido proeminente, seu caráter reflete, em parte, o impacto dos muitos grupos diferentes que hoje compõem a população norte-americana (2012, p. 460).

Com uma considerável margem de certeza, é possível afirmar que o processo de integração ocorrido no Brasil possui algumas características que o aproximam do modelo melting pot, ainda que não possamos falar de um modelo puro desta natureza, para explicar a configuração de diferentes sociedades hibridizadas. Esta análise pode bem ser amparada em Darcy Ribeiro, cuja reflexão demonstra que não ocorreu no Brasil nada parecido com o que sucedeu nos países rioplatenses, onde uma etnia original numericamente pequena foi submetida por massas de imigrantes que, representando quatro quintos do total, imprimiram uma fisionomia nova, caracteristicamente europeia, à sociedade e à cultura nacional, transfigurando-os de povos novos em povos transplantados. Segundo este antropólogo, “(...) o Brasil nasce e cresce como um povo novo, afirmando cada vez mais essa característica em sua configuração histórico-cultural" (1995, p. 242-243). O assinalável no caso brasileiro, segundo Ribeiro, é, por um lado, a desigualdade social, expressa radicalmente na estratificação pela posição inferiorizada do negro e do mulato. E, por outro lado, a homogeneidade cultural básica, que transcende tanto as singularidades ecológicas regionais, bem como as marcas decorrentes da variedade de matrizes raciais, como as diferenças oriundas da proveniência cultural dos distintos contingentes (1995, p. 243).

\footnotetext{
${ }^{9}$ Lugar de reconstrução e de violenta mistura; mistura de raças; cadinho; crisol.
} 
Um terceiro modelo de integração entre maiorias e minorias é o pluralista, segundo o qual as culturas étnicas têm validade plena para existir separadamente, mas devem participar da vida econômica e política da sociedade maior. Este é um modelo que pode ser situado, tanto fática quanto teoricamente, a partir da década de 1960 (KYMLICKA, 1996, 2001, 2003; 2004).

Nesta época teve início uma grande revolução comportamental como o surgimento do feminismo e os movimentos civis em favor dos negros e homossexuais. Esta situação é bem compreendida por Hobsbawn, em The Age of Extremes, ao localizar com precisão as mudanças extraordinárias que se desenvolveram no último terço do século XX. Segundo esse historiador, era um mundo em que os comentadores das mais diferentes vertentes políticas referiam-se à "bússola" que não estava funcionando, em que cada certeza aparente da sociedade - a família, o trabalho, a nação e mesmo a própria afluência foram questionados (2002). O que é preciso destacar, dentro do foco deste trabalho, a partir de Hobsbawn, é a emergência de um mundo completamente diferente em sua configuração, já não mais homogêneo, mas com uma ampla fragmentação que emergiu também sob a faceta cultural, tanto no plano territorial das cidades, como dos próprios Estados. O mundo começava a sair de uma configuração mundial bipolarizada, homogeneizada, para novas formas de representação muito mais complexas, multifacetadas, multiculturalizadas. Da homogeneidade emergia a multi ou pluriculturalidade.

Os movimentos multiculturalistas que iniciaram nos anos 60 do século passado, aumentaram significativamente com a queda do muro de Berlim, evento após o qual todas as sociedades do bloco comunista passaram a conviver com reclamações por respeito às diferenças, especialmente étnicas - e a questão da Bósnia talvez seja o mais sensível desses casos (PAREKH, 2000). O que todos esses movimentos tinham em comum era a necessidade de reconhecimento de suas diferenças culturais. Não desejavam - salvo em casos bem pontuais - que as especificidades de sua própria cultura suplantassem definitivamente o ideal nacional já estabelecido, ou mesmo que seus membros fossem considerados apartados do cenário cultural do Estado-nação. Apenas desejavam ser reconhecidos dentro da nação à qual pertenciam, como portadores de características particulares que os diferenciavam da população ainda adstrita à ideia de cidadania nacional (SEMPRINI, 1999).

Não é nenhum delírio de importância destacar que a pluralidade cultural é, na contemporaneidade, uma realidade e uma virtude das sociedades democráticas que deve ser cada vez mais estimulada e projetada institucionalmente nos sistemas democráticos, tanto em termos formais quanto substanciais. Assim, o fato de diferentes culturas postularem o mesmo direito de 
exercerem, num mesmo país, as suas diferenças, exige das democracias uma espécie de mediação entre a igualdade e a diferença, entre constâncias da maioria e devires criativos das minorias, na medida em que sua universalidade comporta (ALCALÁ, 2005; TORRE, 2000).

Por outro lado, é preciso não deixar de destacar que a estrutura e a funcionalidade do Estado, em função de sua centralização, favorece a homogeneização, enquanto a cidade, em razão de ser e espaço geopolítico onde acontecem os microcosmos sociais, favorece a existência e permanência das ambivalências, evitando assimilações forçadas.

\section{DIÁLOGOS ENTRE MAIORIAS E MINORIAS E SUSTENTABILIDADE DEMOCRÁTICA NA CIDADE}

Repensar a democracia na contemporaneidade exige repensá-la a partir da complexidade do mundo contemporâneo em seus mais distintos espaços de organização comunitária e política. Se o padrão democrático da modernidade esteve fortemente vinculado ao Estado-nação, a crescente importância dos espaços das cidades e as sucessivas crises do espaço de organização política e econômica nacional impõem a reinvenção democrática em novos âmbitos geopolíticos.

Por outro lado, se a pluralidade de culturas em um mesmo espaço e em um mesmo momento é algo que não se pode mais negar, nem tampouco evitar, assim como a ideia de que uma mera sobreposição dessas diversidades demonstra ser prejudicial ao desenvolvimento democrático, é preciso também considerar a necessidade de arranjos democráticos que tomem em conta o problema da diversidade e das minorias. Sobre esse aspecto, o caminho que parece se apresentar como alternativa de re-simbolização ao espaço democrático nacional bifurca-se, pelo menos, em duas direções: primeiro, como já evidenciado ao longo de todo o texto, há uma urgente necessidade de um deslocamento densificador da democracia, partindo do espaço geopolítico nacional em direção ao âmbito da cidade; segundo, precisamos de formas de instituicionalização onde o pluralismo social possa materializar-se através de uma dialética da interculturalidade, apoiado numa ideia de sustentabilidade democrática multifacetada, pela criação de espaços decisórios onde todos os segmentos populacionais tenham possibilidade efetiva de participação, e não apenas uma participação ficcional, como tem acontecido nas democracias representativas nacionais, criando uma ilusão de que o poder emana do povo e de que efetivamente as pessoas governam. A ideia de que todo poder emana do povo, própria das democracias representativas com preponderância nacional, é uma inegável hipóstase da efetividade do poder popular nos processos decisórios públicos. 
A criação de espaços públicos que possibilitem o desenvolvimento de diálogos interculturais e intercomportamentais, entre maiorias e minorias, é um dos importantes trilhos para uma reinvenção democrática sustentável, elemento importante de coesão e harmonia social, especialmente em sociedades com alto grau de diversidade e de instabilidade democrática como as da América Latina.

Esse conceito de sustentabilidade, mesmo que não recente, ainda não parece ter sido compreendido e implementado, correndo o risco de sofrer uma absorção pelo discurso econômico-mercantil hegemônico acerca do desenvolvimento sustentável, que vem ocorrendo desde sua oficialização em âmbito internacional.

A sustentabilidade democrática, em seu multifacetamento, pode e deve englobar outras dimensões de sustentabilidade, tais como trabalhadas por Sachs (1993), conforme apresentamos abaixo em apertado resumo:

1. Dimensão social: trata-se de um processo de desenvolvimento baseado na distribuição de renda, a fim de reduzir a distância entre os padrões de vida de abastados e não abastados;

2. Dimensão econômica: deve ser avaliada mais em termos macrossociais do que apenas por meio de critérios pontuais de lucratividade empresarial, com o intuito de promover mudanças estruturais que atuem como estimuladores do desenvolvimento humano sem comprometer o meio ambiente natural;

3. Dimensão ecológica: propõe um sistema produtivo mais eficiente com soluções ecologicamente corretas e economicamente viáveis através do uso de tecnologias limpas e fontes de energia alternativa renováveis;

4. Dimensão espacial: sugere um dimensionamento espacial adequado, onde haja equilíbrio entre as populações rural e urbana;

5. Dimensão cultural: propõe um novo modelo desenvolvimentista que valorize a continuidade das tradições e pluralidade dos povos.

Por óbvio que todas são importantes e têm estreito vínculo com as atividades humanas, entretanto, para os fins deste trabalho as que se demonstram mais caras são as chamadas dimensões social e cultural da sustentabilidade democrática. Aliadas essas concepções ao que apresentado até o momento parece inegável que a sustentabilidade cultural é resultado direto de um avanço da multiculturalidade em direção à interculturalidade, e, por outro lado, é premissa da realização da democracia em relação a um de seus aspectos mais palpáveis e concretos: o reconhecimento da diversidade nos processos de tomada de decisão pública. 
Essa relação pode ser percebida pela ideia apresentada por Mancini (2009, p. 17), segundo o qual o mundo multicultural pressupõe uma justaposição de etnias ou grupos em uma cidade ou nação, admitindo-se a diversidade, porém com frequente segregação, ao passo que uma estrutura intercultural implica em confrontação e entrelaçamento, em "relações de negociação, conflito e empréstimos recíprocos".

Ora, se por democracia (respeitadas as nuances e formas de realização desenvolvidas ao longo dos anos), pode-se dizer, de forma sintética, que se trata da possibilidade de participação de todos os cidadãos na escolha de seus representantes e na participação ativa nas decisões a respeito do espaço em que vivem (BOBBIO, 2007), então, a cidade é o lócus democrático por excelência; é onde a democracia deixa de ser abstração jurídico-política para se tornar concreta, perceptível aos sentidos.

Seguindo este raciocínio, uma cidade onde a diversidade ou o devir das minorias sejam negados, ou, se reconhecida suas existências, não exista diálogo, é um local, em que a democracia existe de forma muito incipiente, ou somente no seu sentido formal, ao passo que, em um espaço onde haja convergência das diferenças, debate, diálogo, aceitações e tensões dialéticas, encontrase um local que se pode chamar democrático em sentido material.

Assim, tem-se a sustentabilidade cultural como basilar à sustentabilidade democrática: a interculturalidade pondo em contato o diferente, buscando no espaço da cidade o equilíbrio dentro dessa diversidade, o que só se pode dar através da dialética, do debate, da criação do espaço comum de discussão. Neste aspecto, cabe recorrer às palavras de Annan, para quem:

A necessidade de diálogo entre as civilizações é tão antiga quanto a própria civilização. Hoje, entretanto, a necessidade é mais aguda do que nunca. Indivíduos que vivem em uma situação de temor e falta de compreensão sobre outras culturas estão mais propensos a recorrer a atos de ódio, violência e destruição contra aquilo que entendem como "inimigo". Aqueles que são expostos a outras culturas e aprendem sobre elas através da comunicação ultrapassando barreiras culturais tem maior probabilidade de enxergar a diversidade como uma força e celebrá-la como um presente (2001, p. 8).

O que é importante destacar é que a democracia moderna, com raízes liberaisnacionalistas, cada vez mais apresenta sinais de debilidade, como procedimento e substância, por impossibilidades ou redução de possibilidades de diálogos, em um mundo cada vez mais plural e complexo. A crise de legitimidade do Estado nacional, especialmente em função de sua crescente fraqueza para o cumprimento de suas múltiplas e cada vez mais avultantes obrigações, exige que repensemos a centralidade do espaço geopolítico nacional como sendo o principal lugar da 
democracia. Por outro lado, a diversidade de interesses que compõem o espectro social da maior parte das sociedades contemporâneas coloca, pelo menos, a necessidade de questionarmos cada vez mais os sistemas políticos democráticos baseados na estrutura de autoridades centrais (legislativo e executivo) que deliberam para grandes massas populacionais residentes em territórios imensos.

Nos dias atuais estão surgindo inovações e experimentações de formas coletivas de governança democrática e de decisão comunitária na cena urbana (MONTGOMERY, 2003; HEALEY, 1995), fóruns nos quais o foco decisório é a efetivação de direitos humanos. Falamos de experiências que vão desde o orçamento participativo de Porto Alegre e de muitos outros municípios que levaram a sério os ideais da Agenda 21, passando por associações de vizinhos como ocorre em Madri (CASTELLS, 1985), ou por associações voluntárias que progressivamente se colocam a cargo de espaços públicos e comunitários, até as heterotópicas ilhas de diferença que excluem poderes corporativos e que constroem sistemas locais de trocas econômicas ou comunidades sustentáveis.

A criação de novos espaços urbanos comuns, de uma esfera pública de participação democrática, exige desfazer toda uma semiologia nacionalista, para pensarmos alternativas de uma democracia mais inclusiva, mesmo se continuamente fracionada, baseada não apenas em uma ordenação diferente de direitos, mas de práticas político-econômicas.

Nesse sentido, as formas de empoderamento social são cada vez mais alternativas rizomáticas de reinvenção democrática, e a democracia não pode significar apenas um direito incondicional de acesso àquilo que já existe, mas sim um direito ativo de fazer a cidade diferente, de formá-la mais de acordo com nossas necessidades coletivas, definindo maneiras alternativas de simplesmente ser humano (HARVEY, 2013, p. 33). O texto constitucional de 1988 já abriu esse caminho que, entretanto, ainda encontra-se totalmente subutilizado, em função do campo gravitacional estatal que praticamente subordina todas as formas de participação e controle popular do sistema democrático. Exemplo dessa situação são os Conselhos municipais e estaduais de políticas públicas ${ }^{10}$, cuja atuação é até mesmo tragada e anulada pelos poderes executivo e legislativo municipais.

\footnotetext{
${ }^{10}$ Art. 29. O Município reger-se-á por lei orgânica, votada em dois turnos, com o interstício mínimo de dez dias, e aprovada por dois terços dos membros da Câmara Municipal, que a promulgará, atendidos os princípios estabelecidos nesta Constituição, na Constituição do respectivo Estado e os seguintes preceitos:
} 
Ainda que os Conselhos de Políticas Públicas sejam objeto de várias normatizações legais, suas atuações são de importância reduzida no sistema de tomada de decisões públicas. A fim de potencializar esses espaços de consolidação democrática, temos que os Conselhos:

1. Devem ter poder deliberativo, em paridade de forças com os poderes públicos;

2. Devem levar em consideração as reivindicações dos diversos grupos sociais e atuar na implementação e controle dessas políticas;

3. Devem ser criados por iniciativa do executivo ou, em caso de omissão deste, por uma ação civil pública. A via judicial deve ser uma alternativa para casos extremos. A negociação política é sempre desejável para que o conselho a ser criado nasça baseado na cooperação e não no dissenso;

4. Devem ser representativos de legítimas instituições atuantes nos segmentos ligados à área de atuação do conselho;

5. Devem ser compostos de forma paritária por representantes do governo e da sociedade. 0 estabelecimento da paridade vai depender da área temática, dos representantes e também da história, democrática e participativa, ou não, que levou à construção do conselho; e

XII - cooperação das associações representativas no planejamento municipal. Art. 194. A seguridade social compreende um conjunto integrado de ações de iniciativa dos Poderes Públicos e da sociedade, destinadas a assegurar os direitos relativos à saúde, à previdência e à assistência social.

Parágrafo único. Compete ao Poder Público, nos termos da lei, organizar a seguridade social, com base nos seguintes objetivos:

VII - caráter democrático e descentralizado da administração, mediante gestão quadripartite, com participação dos trabalhadores, dos empregadores, dos aposentados e do Governo nos órgãos colegiados.

Art. 198. As ações e serviços públicos de saúde integram uma rede regionalizada e hierarquizada e constituem um sistema único, organizado de acordo com as seguintes diretrizes:

III - participação da comunidade.

Art. 204. As ações governamentais na área da assistência social serão realizadas com recursos do orçamento da seguridade social, previstos no art. 195, além de outras fontes, e organizadas com base nas seguintes diretrizes:

II - participação da população, por meio de organizações representativas, na formulação das políticas e no controle das ações em todos os níveis.

Art. 206. O ensino será ministrado com base nos seguintes princípios:

VI - gestão democrática do ensino público, na forma da lei;

Art. 227. É dever da família, da sociedade e do Estado assegurar à criança, ao adolescente e ao jovem, com absoluta prioridade, o direito à vida, à saúde, à alimentação, à educação, ao lazer, à profissionalização, à cultura, à dignidade, ao respeito, à liberdade e à convivência familiar e comunitária, além de colocá-los a salvo de toda forma de negligência, discriminação, exploração, violência, crueldade e opressão.

$\S 1$ O O Estado promoverá programas de assistência integral à saúde da criança, do adolescente e do jovem, admitida a participação de entidades não governamentais, mediante políticas específicas e obedecendo aos seguintes preceitos: 
6. Devem dispor de fundos para financiar políticas específicas. Os recursos para o funcionamento dos conselhos devem ser assegurados no orçamento federal, do Estado ou do município.

\section{CONCLUSÃO}

Não há mais qualquer sombra de dúvida acerca de uma complexificação sociocultural cada vez maior das sociedades contemporâneas, em decorrência de uma intensificação sem precedentes dos fluxos, tanto de pessoas quanto de informações. Também está evidente que este multifacetamento se faz sentir materialmente muito mais na cidade do que em qualquer outro espaço geopolítico. Por outro lado, não há como negar que as democracias representativas nacionais, em países com altos contingentes populacionais, enfrentam, hodiernamente, situações de crise não só de representação, mas, no plano material, de efetividade na concretização de direitos humanos dos distintos grupos que compõem a população, especialmente aqueles que não se enquadram nas constâncias do grupo majoritário. Diante disso, para (re) pensarmos a democracia em configurações sociais marcadas pela alta complexidade, como acontece na atualidade, é preciso que foquemos reflexões e práticas sobre alguns aspectos, tais como:

1. Primeiro, novos arranjos democráticos devem levar em consideração a complexidade contemporânea, em termos de maiorias e minorias e em relação ao conjunto de direitos humanos que, no processo civilizatório, conseguimos construir até o momento, para reinventá-lo, a fim de reduzirmos, o máximo, possível, as violências e segregações que têm sido impostas pelos processos de dominação engendrados pelas maiorias;

2. Segundo, as segregações e violências direcionadas historicamente contra minorias têm uma séria repercussão no enfraquecimento e na falta de competitividade das minorias nos processos de tomada de decisão pública, o que, num contra fluxo consequencial, reenviaas a situações de violência e segregações, pois as minorias, ao não terem vigor nos processos de democracia representativa, também ficam vulnerabilizadas na concretização de seus direitos humanos ligados às suas condições minoritárias, ou seja, ao não conseguirem participar competitivamente para decidirem a seu favor, não conseguem concretizar seus direitos e interesses, o que leva a permanecerem enfraquecidos e sem vigor para participarem no sistema de democracia representativa;

3. Terceiro, a materialização dos multifacetamentos socioculturais ocorre mais intensamente no espaço da cidade do que no do Estado nacional, e, sendo assim, é preciso reconsiderar 
a importância dos âmbitos decisórios próprios da cidade, o que nos conduz a afirmar que não é possível, nem admissível priorizarmos, em sociedades multifacetadas, os processos democráticos unicamente dentro dos cânones da democracia representativa nacional, onde a tendência é a homogeneização e a liquidação das ambivalências pela hegemonia da maioria;

4. Quarto, os espaços citadinos de acontecimento da democracia, como ocorrem na atualidade nos sistemas federativos, especialmente aqueles altamente centralizados como o brasileiro, são repetições desvitalizadas das institucionalizações "democráticas nacionais", e muito pouco ou praticamente nada agregam a uma real democratização dos sistemas de tomada de decisão pública, ainda mais se focarmos desde uma perspectiva dos direitos humanos das minorias; e

5. Diante desse estado atual, não há como evitarmos pensar e praticar a democracia por caminhos de combinação e ajuste entre processos de tomada de decisão pública, equidade e minorias, e neste aspecto, cada vez mais a democracia moderna representativa deve ceder espaço para formas mais efetivas de democracia e controle social das atividades do Estado, notadamente pelo empoderamento da sociedade civil no âmbito geopolítico das cidades, com a consideração substancial da diversidade e complexidade de suas composições socioculturais.

Necessitamos, enfim, de novas formas de democracia, que deem conta da complexidade do mundo atual, pois somente sistemas de decisão pública com uma complexidade cuja funcionalidade se encarregue de dar conta de reduzir a complexidade de nossas sociedades contemporâneas pode substituir legitimamente a concepção de democrática representativa moderna que perdeu sua capacidade de reduzir a complexidade do mundo da vida que se manifesta hodiernamente.

\section{REFERÊNCIAS BIBLIOGRÁFICAS}

ÁGUILA, Rafael del; VALLESPíN, Fernando y otros (Orgs.). La democracia en sus textos. Madrid: Alianza Editorial, 1998.

ALCALÁ, J. Alberto del Real. Problemas de gestión de la diversidad cultural en un mundo plural. In: RUIZ, Ruiz Ramón; et al. (Editores). Derechos fundamentales, valores y multiculturalismo. Madrid: Dykinson, 2005;

ANNAN, Kofi A. Foreword. In: Giandomenico Picco (org.). Crossing the Divide: dialogue among civilizations. South Orange (USA): Seton Hall University, 2001. 
BACHA, Maria de Lourdes et al. Considerações teóricas sobre o conceito de Sustentabilidade. In: CONGRESSO DE EXCELÊNCIA EM GESTÃO E TECNOLOGIA, 7., 2010, Resende, RJ. Anais Eletrônicos. Resende: AEDB, 2010. Disponível em <http://www.aedb.br/seget/artigos10/31_cons\% 20teor\%20bacha.pdf>. Acesso em: 15 ago. 2013.

BARKAN, Elliot. Race, Religion and Nationality in American Society: a Model of Ethnicity-From Contact to Assimilation. Journal of American Ethnic History, n. 14, 1995, p. 38-101; Introduction: Immigration, Incorporation, Assimilation and the Limits of Transnationalism. Journal of American Ethnic History, n. 25, 2006, p. 7-32;

BOBBIO, Norberto et al. Dicionário de Politica. Brasília: UNB, 2007. 2 v.

BOSHI, R. R. (1999). Descentralização, clientelismo e capital social na governanaça urbana: comparando Belo Horizonte e Salvador. Dados - Revista de Ciências Sociais, v. 42, n. 4, p. 655-690.

BRUBAKER, Roger. The Return of Assimilation? Changing Perspectives on Immigration and Its Sequels in France, Germany and United States. Ethnic and Racial Studies, n. 24, 2001, p. 531-548.

BUREAU OF CENSUS (U. S. DEPARTMENT OF COMMERCE). Celebrating Our Nation's Diversity. Washington D.C., s.d.;

CANCLINI, Néstor García. Diferentes, Desiguais e desconectados. 3 ed. Rio de Janeiro: UFRJ, 2009.

CASTELLS, Manuel. A Era da Informação: Economia, sociedade e cultura. São Paulo: Paz e Terra, 2010.

A Questão Urbana. São Paulo: Paz e Terra, 1983.

Cidade, Democracia e Socialismo. A experiência das associações de vizinhos de Madri. Tradução de Glória Rodrigues. 2. ed. Rio de Janeiro: Paz e Terra, 1985.

DELEUZE, Gilles; GUATTARI, Félix. O que é a filosofia. Rio de Janeiro: Ed. 34, 1992.

Mil Platôs: capitalismo e esquizofrenia 2. São Paulo: Ed. 34, 1995. 5 v.

GANS, Herbert J. The American Kaleidoscope: Then and Now. In: JACOBY, Tamar (ed.). Reinventing the Melting Pot. New York: Basic Books, 2004.

GUEDES, Néviton. A democracia representativa e a separação essencial ente o povo e sua representação. In: GOMES CANOTILHO, J.J.; MENDES, Gilmar Ferreira e outros (Coords.). Comentários à Constituição do Brasil. São Paulo: Saraiva/Almedina, 2013, p. 654-689.

HARVEY, David. Sociologia. 6. ed. Porto Alegre: Penso, 2012.

et al. A liberdade da cidade. In: MONTGOMERY, Mark R. et. al. (org.). Cidades Rebeldes: Passe livre e as manifestações que tomaram as ruas do Brasil. São Paulo: Boitempo/Carta Maior, 2013.

HEALEY, Patsy et. al. Managing Cities: The New Urban Context. New York: Wiley, 1995)

HOBSBAWN, Eric. The Age of Extremes. London: Michael Joseph, 1994; 
JACOBY, Tamar. Defining Assimilations for the 21th Century. In: JACOBY, Tamar (ed.). Reinventing the Melting Pot. New York: Basic Books, 2004;

KARSTEN, Frank; BECKMAN, Karel. São Paulo: Instituto Ludwig von Mises Brasil, 2013.

KYMLICKA, Will. Ciudadanía multicultural. Una teoría liberal de los derechos de las minorias. Traducción de Carme Castells Auleda. Barcelona: Paidós, 1996.

Estados, naciones y culturas. Traducido y adaptado por Juan Jesús Mora. Córdoba: Editorial Almuzara, 2004.

La política vernácula. Nacionalismo, multiculturalismo y ciudadanía. Traducción de Tomás Fernandéz Aúz y Beatriz Eguibar. Barcelona: Paidós, 2003.

STRAEHLE, Cristiane. Cosmopolitismo, Estado-nación y nacionalismo de las minorías. Un análisis crítico de la literatura reciente. México: Universidad Autónoma de México, 2001.

LOJKINE, Jean. O Estado Capitalista e Questão Urbana. São Paulo: Martins Fontes, 1997.

LUCAS, Doglas Cesar. Direitos Humanos e Interculturalidade: um diálogo entre a igualdade e a diferença. 2. ed. ljuí: Unijuí, 2013.

LUÑO, Antonio Enrique Perez. Derechos humanos, Estado de Derecho y Constitución. Madrid: Tecnos, 1999.

Los Derechos Fundamentales. 6. ed. Madrid: Tecnos, 1995.

MENDRAS, Henri. Georg Simmel. Sociologie et Épistémologie. Revue française de sociologie. 1983, v. 24, n.1, p. 137-140.

MILL, John Stuart. Utilitarism, Liberty and Representative Government. Maryland, USA: Wildside Press, 2007.

MITCHELS, Robert. Sociologia dos Partidos Políticos. Brasília: UnB,1982.

MONTGOMERY, Mark R. et. al. (org.). Cidades Rebeldes: passe livre e as manifestações que tomaram as ruas do Brasil. São Paulo: Boitempo/Carta Maior, 2013.

PAREKH, Bhikhu. Repensando el multiculturalismo. Diversidad cultural y teoría política. Traducción de Sandra Chaparro. Madrid: Istmo, 2000.

PARK, Roberta Ezra. A Cidade: Sugestões para a investigação do comportamento humano no meio urbano In: VELHO, Otávio Guilherme (org.). O Fenômeno Urbano. 4 ed. Rio de Janeiro: Zahar Editores, 1979.

PAULISTA, Geralda et al. Espaço Emocional e Indicadores de Sustentabilidade. Ambiente e Sociedade. Campinas: v. 11, n. 1, 2008. Disponível em: <http://www.scielo.br/pdf/asoc/ v11n1/12.pdf>. Acesso em: 08 out. 2013.

PEREIRA, João Vitor Inácio. Sustentabilidade: diferentes perspectivas, um objectivo comum. ECOLINE. São Paulo, 2007. Disponível em: <http://www.scielo.oces.mctes.pt/pdf/egg/v14n1/v14n1a08.pdf>. Acesso em: 08 out. 2013.

PIOVESAN, Flávia. Igualdade, diferença e Direitos Humanos. Rio de janeiro: Lúmen júris, 2008. 
RIBEIRO, Darcy. O Povo Brasileiro. A formação e o sentido do Brasil. 3. ed. São Paulo: Companhia das Letras, 1995.

SACHS, Ignacy. Caminhos para o Desenvolvimento Sustentável. Rio de Janeiro: Garamond, 2002.

Estratégias de Transição para o Século XXI: Desenvolvimento e Meio Ambiente. São Paulo: Fundap, 1993.

SANTOS, André Leonardo Copetti. OS ORIXÁS CONTEMPORÂNEOS E A CIDADE INVISÍVEL. Potências da Cidadania pelo Desenvolvimento de uma Sensibilidade Urbana. Revista Direito e Justiça: Reflexões Sociojurídicas, v. 13, n. 21. Santo Ângelo: 2013, p. 83-110.

SANTOS, Milton. Por uma Geografia Nova. 3 ed. São Paulo: Hucitec, 1986.

SARLET, Ingo Wolfgang. A eficácia dos direitos fundamentais. 6. ed., Porto Alegre: Livraria do Advogado, 2006.

SENNET, Richard. Carne e Pedra: o corpo e a cidade na civilização ocidental. Rio de Janeiro: BestBolso, 2010.

SASSEN, Saskia. Una sociología de la globalización. Buenos Aires: Katz, 2007.

SEMPRINI, Andrea. Multiculturalismo. Tradução de Laureano Pelegrin. Bauru: EDUSC, 1999.

SIMMEL, Georg. Questões Fundamentais de Sociologia. Rio de Janeiro: Jorge Zahar Editor, 2006.

TOBAR, Marcela Ríos. Introducción. In: TOBAR, Marcela Ríos (Ed.). Mujer y política. El impacto de las cuotas de gênero en América Latina. Santiago, CH: Catalonia, 2008, p. 13-26.

TORRE, Giuseppe Dalla. La multiculturalità come dato di fatto e come programma etico-politico. In: TORRE, Giuseppe Dalla; D'AGOSTINO, Francesco (Orgs.). La cittadinanza. Problemi e dinamiche in una società pluralística. Torino: G. Giappichelli Editore, 2000.

VERTOVEC, S. (2007). "Superdiversity' and its implications". Ethnic and racial studies. v. 30, n. 6, pp. 1024-1054.

YOUNG, Jock. A sociedade excludente. Exclusão social, criminalidade e diferença na modernidade recente. Rio de Janeiro: Revan, 2002.

Trabalho enviado em 07 de setembro de 2015.

Aceito em 05 de dezembro de 2015. 